IZA DP No. 6587

A Price for Flexibility?

The Temp Agency Wage Gap in Sweden 1998-2008

Pernilla Andersson Joona

Eskil Wadensjö

May 2012 


\title{
A Price for Flexibility? The Temp Agency Wage Gap in Sweden 1998-2008
}

\author{
Pernilla Andersson Joona \\ SOFI, Stockholm University \\ and IZA \\ Eskil Wadensjö \\ SOFI, Stockholm University \\ and IZA
}
Discussion Paper No. 6587
May 2012

IZA
P.O. Box 7240
53072 Bonn
Germany

Phone: +49-228-3894-0

Fax: +49-228-3894-180

E-mail: iza@iza.org

\begin{abstract}
Any opinions expressed here are those of the author(s) and not those of IZA. Research published in this series may include views on policy, but the institute itself takes no institutional policy positions.

The Institute for the Study of Labor (IZA) in Bonn is a local and virtual international research center and a place of communication between science, politics and business. IZA is an independent nonprofit organization supported by Deutsche Post Foundation. The center is associated with the University of Bonn and offers a stimulating research environment through its international network, workshops and conferences, data service, project support, research visits and doctoral program. IZA engages in (i) original and internationally competitive research in all fields of labor economics, (ii) development of policy concepts, and (iii) dissemination of research results and concepts to the interested public.
\end{abstract}

IZA Discussion Papers often represent preliminary work and are circulated to encourage discussion. Citation of such a paper should account for its provisional character. A revised version may be available directly from the author. 


\section{ABSTRACT}

\section{A Price for Flexibility? The Temp Agency Wage Gap in Sweden 1998-2008*}

Temporary agency employment has grown rapidly in Sweden as in many other countries. The sector was deregulated in the early 1990s and there are now only few remaining restrictions. Even though there are collective agreements covering a large part of the workers in the sector, the unions are worried about low wages and poor working conditions in the sector. This paper analyzes the development of the temporary agency wage gap during the period 1998-2008 using Swedish register data. We find that from a nearly non-existent gap in 2001 and a positive wage gap for women, both male and female temp agency workers received between 16 and 18 percent lower wages in 2008. This development appears partly to be explained by a lower return to university education among temp agency workers than among those employed in other sectors.

JEL Classification: J31, J42, J62

Keywords: temporary agency employment, wages

Corresponding author:

Pernilla Andersson Joona

Swedish Institute for Social Research

Stockholm University

SE 10691 Stockholm

Sweden

E-mail: pernilla.andersson.joona@sofi.su.se

\footnotetext{
* We want to thank Per Lundborg and seminar participants at the workshop on labor market flexibility in Nuremberg, the ESPE annual conference in Hangzhou, the EALE annual conference in Cyprus, Ratio and the Centre for Economic Demography at Lund University. Andersson Joona gratefully acknowledges funding from Jan Wallander's and Tom Hedelius stiftelse and both of us for funding from the Swedish Council for Working Life and Social Research (FAS) and the Swedish Research Council.
} 


\section{Introduction}

The history of temporary employment agencies is rather short in most countries, but in Sweden, as in many other countries, the sector has rapidly grown. In 1998, about 11,000 people in Sweden were employed in the sector and in 2008 the number had increased to about 51,000 corresponding to 1.2 percent of all employed. ${ }^{1} \mathrm{Up}$ to the $1990 \mathrm{~s}$, temporary employment agencies together with private employment agencies were forbidden in many countries or regulated in such a way that their activities remained limited. In the early 1990s, Sweden as many other countries went from prohibition to a state with very few restrictions besides those valid for employers in other sectors. ${ }^{2}$ The main remaining restriction in Sweden is that it is not allowed to charge a fee to employees looking for a job or being hired out to another employer, but only to the employers who hire a worker or rent a temp. Some other countries have other restrictions, for example regarding in which occupations or industries it is possible to hire workers from a temp agency or regarding the length of the hiring period.

Temporary agency work in Sweden is however covered by collective agreements between the employer association for the temp agencies ${ }^{3}$ and the unions. These agreements regulate wages and other working conditions for the temps. The conditions under which client firms can hire temp workers are also regulated in collective agreements for industries that hire temps. The unions and the employer associations in these industries are the parties in these agreements and the conditions were a major issue in the negotiations for collective agreements in Sweden in 2010.

During the last few years, wages and other working conditions of temp agency workers have become widely debated in Sweden, but little is in fact known about the wages of temp workers. This paper is the first study of the temp wage gap in Sweden.

\footnotetext{
${ }^{1}$ Own calculations based on the Employment Register at Statistics Sweden for 1998 and 2008.

${ }^{2}$ For the early history of temporary agencies in Sweden, see Wadensjö (1990), Friberg, Olli and Wadensjö (1999) and Johnson (2010).

3 "Bemanningsföretagen", www.bemanningsforetagen.se
} 
There are arguments for higher wages as well as for lower wages for temp workers compared with those of other workers. ${ }^{4}$ The theory of compensating wage differentials (Rosen 1986) suggests that workers with less appealing jobs should be compensated for this in terms of higher wages. There is some empirical evidence of that temp work is associated with lower tenure (Antoni and Jahn 2009) and a higher incidence of work injuries (Fabiano et al. 2008) and higher temp wages could compensate for that. One argument for why temp wages should be lower is that the worker accepts the lower wage hoping that this will pay off in terms of a better job and a higher wage in the future. Another argument is that the temp agency offers free general training instead of paying higher wages (Autor 2001).

Wages and other conditions of the temp workers have been the topic of studies in different countries. Most of them find that temp workers receive lower wages than workers with other employment arrangements. One of the first studies that analyses the temp wage gap is Segal and Sullivan (1998), who used administrative data for one state in the US. They find a temp wage gap of about 10 percent. Case study evidence from hospitals and manufacturers in the US suggests that temp agency workers in high-skilled occupations in hospitals are paid more than regular employees while the opposite is true for low-skilled workers in manufacturing (Houseman et al. 2003). An early study for Germany finds that also German temp workers have lower wages than workers in other sectors of the economy (Kvasnicka and Werwatz 2002). Recent studies for Germany analyze the temp wage gap after that the temp sector was considerably deregulated (Jahn 2010 and 2010a). It is found that the wages are much lower for workers in the temp sector than for other employees, but that the main part of the difference disappears when controls are included for different characteristics such as education and when a specification with individual fixed effects is estimated. The remaining wage difference, however, is not negligible; 15 percent lower wages. When the future career

\footnotetext{
${ }^{4}$ See Jahn (2010) for a thorough discussion of the arguments.
} 
of the temporary help agency workers are studied the result is that there are no long-lasting negative effects of having been employed by a temporary help agency - the wage reduction is only in the period as a temp.

A recent study investigates whether the temp wage gap varies with intensity of exposure to temp agency employment (Jahn and Pozzoli 2011). The intensity of temp agency work is measured as the cumulative number of weeks in temp agency employment over the past five years. The wage penalty from temp agency work decreases with time spent working in the sector, and the estimated earnings gap decreases with time in the industry when analyzing post-temp earnings.

Forde and Slater (2005) analyze the temp wage gap in Britain and find that male agency workers have about 11 percent lower wages and female agency workers about 6 percent lower wages. Böheim and Cardoso (2009) who study the wages of temp workers in Portugal in 1995-2000 find that wages on average are considerably lower for temp workers than for those employed in other industries; about 23 percent lower. Controlling for different characteristics such as education, the difference is reduced to 9 percent. When studying those who change industry through the inclusion of individual fixed effects, the wage difference is further reduced to 3 percent. A study of separate age groups shows that young people get a higher wage when working in the temporary agency industry but older workers a lower wage in both cases compared to working in other industries.

Even if most previous studies find a temp agency wage gap, workers might still benefit from temp agency work in terms of future employment chances. The so called stepping-stone hypothesis is perhaps the most studied question concerning the temporary employment agencies (Amuedo-Dorantes et al. 2008; Ichino et al 2008; Andersson et al. 2009; Heinrich et al. 2009; Kvasnicka 2009; Jahn and Rosholm 2010). The results are mixed and vary by country and target group. 
In this paper we use register data for the period 1998-2008 to analyze the temp agency wage gap in Sweden. The Swedish labor market differs in many respects from those in other European countries and the US, which makes a study for Sweden a contribution to the existing literature. The fact that the working conditions for temp workers have become a widely debated question in Sweden also calls for an analysis of the temp wage gap.

One of the main findings of this paper is that the development of wages in the temp sector differs substantially from that in the labor market as a whole. In particular, we find that the average wage in the temp sector has decreased after 2001, which has led to an increase in the temp agency wage gap. Trying to explain the decline in wages we explore and discuss the following hypotheses: (i) changes in the supply and demand for temp agency workers, (ii) declining returns to education in the temp agency sector, (iii) decreased entry wages, (iv) differences in wage growth, and (v) the importance of collective agreements.

The outline of the rest of the paper is as follows. In section two the data are described and some sample statistics presented, in section three we analyze how average wages in the temp sector have evolved over time and compare them to wages on the whole labor market and, in section four we try to explain the increased temp agency wage gap by investigating our five hypotheses. Section five summarizes and concludes the paper.

\section{Data and descriptive statistics}

Our analysis of the wages in the temporary agency sector is based on individual data from Statistics Sweden's yearly register over the population in Sweden during the period 1998-2008. ${ }^{5}$ The register covers everyone who had been employed in this period. According to Statistics Sweden's definition, an individual is employed a certain year, if the income received in November exceeds a certain low amount, which varies by age, gender and some

\footnotetext{
${ }^{5}$ For a detailed presentation of the statistics regarding temporary employment agencies, see Andersson and Wadensjö (2004).
} 
other background characteristics. ${ }^{6}$ The fact that only one month, November, has been selected means that many seasonal workers are not included.

Since we are interested in the development of wages in a certain industry one key element of the data is that we are able to identify the industry in which a worker was employed in November. Since 2002 the temp agency sector has its own sector code in the register. To be able to identify temp agencies prior to 2002 potential temporary agencies were identified by using the yellow pages and the internet. This was done during the period 20012002 and the firms were eventually contacted by phone and asked about their main activity. Statistics Sweden then applied our definition of temp agency firms to the firms in its register.

In Statistics Sweden's register over the population there is no information on wages, only on annual earnings. However, in other registers administrated by Statistics Sweden there is information on monthly wages for the whole public sector and for a sample of employees in the private sector. About 50 percent of those employed by firms in the private sector are included each year. One problem performing panel data analysis using the wage data for the private sector is that we have an unbalanced panel. Workers drop out of the panel, not only because they are not employed any more, have moved out of the country, have retired or died, but because they work at a firm that is not included in the sample a certain year.

Information on wages is collected by Statistics Sweden directly from the firms. Monthly wages, which are used as dependent variables in the present analysis, are transformed into fulltime equivalents. Temp agency workers have in many cases a full time contract with the temp agency but are perhaps not hired out to client firms on a full time bases. During hours when they are not hired out but for example have to be on call at home, they receive a so called guarantee wage which in most cases corresponds to 90 percent of the average wage they have received during the last three months. It must however be noted that the wage

\footnotetext{
${ }^{6}$ See SCB, Registerbaserad arbetsmarknadsstatistik (RAMS), http://www.scb.se/Pages/List__ 259025.aspx
} 
reported to Statistics Sweden is not based on the guarantee wage but only on the wage for hours worked that has been agreed upon. ${ }^{7}$ The hourly wage for those hours worked are then used to calculate the wage for full-time work.

One group of workers is particularly problematic to handle in the data. This group is called "moving personnel" and consists of workers that cannot be matched to a certain workplace. Construction workers are one such group. Among temp agency workers this is a rather large group. Even if they are employed by one firm, they often switch workplaces where the actual work is performed. We have chosen to exclude these workers even if they in some years are numerous among temp agency workers. See table A1. The reason for doing so is that in most regressions we include controls for the number of employees at the workplace since this is assumed to affect wages and this information is missing for all workers who are defined as "moving personnel". A simple OLS regression among temp agency workers shows that the moving personnel have about 6.5 percent lower wages on average than other temp agency workers. The baseline regression for the temp agency wage gap has also been estimated including moving personnel and not controlling for number of employees. The temp agency wage gap is then larger and the estimates presented in the paper should therefore be viewed as a conservative estimate of the gap.

In addition to information on sector, wages and number of employees, we also have information on standard demographic variables such as age, gender, family status, number of children, education, place of residence and country of origin. From 2001 on the data also contains information on occupation. Since this is an important variable for explaining wages, the main part of the regression analysis will be estimated for the period 2001-2008.

\footnotetext{
${ }^{7}$ Information in an e-mail from Marie Lidéus, Head of the unit for wage and labor costs statistics, Statistics Sweden, February 23, 2012.
} 
Among temp agency workers we cannot distinguish the administrative personnel from employees hired as consultants. The administrative personnel constitute, however, only a small part of those employed by temp agencies.

During our observation period the sector has increased substantially in terms of number of workers; from about 11,000 employees in November 1998 to about 50,000 employees in November 2008. This increase has essentially been linear with the exception from a few years around 2005 where the number of employees temporarily dropped. See Figure 1.

\section{[FIGURE 1 ABOUT HERE]}

In Table 1 we present sample means for temp agency workers and for employees working in other sectors of the economy in 2001 and 2008. Note that workers defined as moving personnel and part-time workers in the public sector have been excluded. The average age among temp agency workers were 15 years lower in 2001 and ten years lower in 2008 . When the sample is divided into five age groups, it is evident that workers between 16 and 24 years are heavily overrepresented in the temp industry. Those aged 25-34 years are also overrepresented but not by as much. The female share of those employed in the temp sector was 63 percent in 2001 but declined to 47 percent in 2008. An overrepresentation of women in the temp agency sector in 2001 has changed into an underrepresentation in 2008. This development is to a large extent explained by that the temp agency sector has expanded into male dominated areas. Foreign born, especially those from non-Western countries, are overrepresented in the temp industry. The share with higher education, i.e. college education, is about 7 percentage points lower among temp agency workers in both years. Comparing monthly wages we see that in 2001 , there was a wage disadvantage of 2,300 SEK that increased to about 6,000 SEK in $2008 .^{8}$

\section{[TABLE 1 ABOUT HERE]}

\footnotetext{
${ }^{8} \mathrm{~A}$ wage in SEK can be divided by 7 to get the approximate wage in US dollars.
} 


\section{Time Trend in the Temps' Wages}

In this section we describe how temp agency sector wages have developed from 1998 to 2008 and compare that to the general wage development in the economy. We also estimate the temp wage gap for each year during our observation period.

The development of mean wages in the temp agency sector and the private sector is plotted separately for men and women in Figure 2 and 3. Mean wages are calculated for all workers in each sector separately for each year without controlling for any background factors. By inspection of the raw differences it is obvious that average full-time monthly earnings ${ }^{9}$ in general are lower for temporary agency workers than for workers in other industries. The gap appears to be larger among men than among women. The development of monthly earnings among workers in the temp sector shows an unexpected pattern. Especially among men we see a sharp increase in earnings between 2000 and 2001 and an almost equally sharp decrease between 2001 and 2002. For wages in other parts of the private sector we do not find such a pattern which implies that the raw temp wage gap changed.

The main part of our is devoted to trying to explain this remarkable pattern. One possible explanation for the development of the wage gap is that the number of (highly paid) medical doctors in the temp agency sector increased much in the late 1990 s and early 2000 s and that in 2003 several county councils, which are in charge of the hospitals, introduced a stop for hiring medical doctors from temporary help agencies. The development of the number of medical doctors employed in the temp industry is presented in Table A2. ${ }^{10}$ Up to 2000 there were only a few medical doctors in the temp industry but in 2001 this occupational group constituted 2.6 percent of all male employees in the sector. If this group is excluded from the calculation of average wages, the wage development pattern changes. The increase between 2000 and 2001 is smaller and the decline between 2003 and 2004 is also less pronounced (see Figure 4), but

\footnotetext{
${ }^{9}$ Statistics Sweden recalculates the wage information received from the employers to full-time monthly earnings. ${ }^{10}$ The medical doctors have been identified by Statistics Sweden by using a combination of educational level and type of education.
} 
that average wages in the sector still decline after 2001. Since medical doctors seem to have a large influence on the wages although they are few, we exclude them from the rest of the analysis.

\section{[FIGURE 2, 3 \& 4 ABOUT HERE]}

Inspection of the graphs revealed that there appears to be substantial variation in the raw temp agency wage gap over time. This could be explained by compositional changes among temp agency workers and to account for this we estimate the following model for the period 2001-2008 ${ }^{11}$

$$
\operatorname{lnw}_{i t}=\alpha+\beta \text { Temp }_{i t}+\gamma \text { Year }_{i t}+\delta \text { Temp }_{i t} * \operatorname{Year}_{i t}+\rho X_{i t}+\varepsilon_{i t}
$$

where $\beta$ is an estimate of the temp wage gap in the reference year which is 2001 , Year is a vector of dummy variables for each year, 2002-2008 and hence the vector $\gamma$ gives us estimates of the overall wage trend. Then we include interactions between temp agency work and year. The estimates included in the vector $\delta$ are measures of the temp agency wage gap for each year compared to 2001. By inspection of these coefficients we can see if the temp wage gap is smaller or larger, relative to the gap in 2001. We also include a vector of background variables: age, age squared, marital status, number of children, education, place of residence, country of origin, participation in education during the year, number of employees at the workplace and occupation at a three-digit level.

In these regressions we include workers in both the private and the public sector. Although temporary employment agencies are firms in the private sector, some of their clients can be found in the public sector. The collective agreements for temp agency workers state that temp agency workers should receive a wage (from the temp agency) which is in line with the average wage of permanent workers at the client firm. This means that reference wages, in particular for some occupational groups, are wages in the public sector. ${ }^{12}$ Among women in

\footnotetext{
${ }^{11} 1998-2000$ are excluded since information on occupation is not available for these years.

${ }^{12}$ Inclusion of controls for sector does not have a significant impact on the temp agency wage gap.
} 
the public sector we exclude those working less than 75 percent since there appears to be a rather strong correlation between monthly wage and agreed working time. Between 21 and 28 percent of female employees in the public sector are excluded due to this restriction, depending on year. We do not have similar information for workers in the private sector.

The results for these regressions are presented in Table 2. For male workers we do not find any significant wage difference between temp agency workers and workers in other industries in 2001. The estimates of the interactions terms are all negative and significant indicating that the temp agency wage gap is larger, i.e. more negative, in all subsequent years than in 2001. For example, the temp agency wage gap was about 5 percent larger in 2002 compared to in 2001 and 18 percent larger in 2008 than in 2001. This clearly shows that the gap has increased over time and that this development cannot be explained by the inclusion of a large set of background factors.

For women we find that there in fact was a positive temp agency wag gap in 2001 and also in 2002, although smaller. However, by 2003 this has turned into a negative gap which increases over time. The finding that the wage gap appears to be smaller among women than among men is in line with previous findings for the British labor market reported in Forde and Slater (2005).

The temp agency industry is a special industry in the sense that it in a way is a reflection of the whole labor market and as such employs workers in different occupations. Average wages in the sector might be influenced by the changes in the occupational composition and therefore we want to look at the development of wages separately by occupation. In 2001, the three largest occupational groups among men were office and customer service work (30.9\%), machine operators $(14.4 \%)$ and occupations which require a short university degree $(7.7 \%)$. In 2008 , this had changed to be machine operators $(25.8 \%)$, craftsmen $(15.6 \%)$ and office and customer service work (13.4\%). For women the most common occupations in 2001 were 
office and customer service work (51.4\%), occupations which require a short university degree (11.4\%) and service and sales workers (10.3\%). In 2008 the order of the three largest occupational groups was the same but now with 32.8 percent, 18.5 percent, and 11.2 percent of all workers, respectively. ${ }^{13}$ These numbers are for all workers in the temp agency industry, not only for workers for which we have information on wages. We estimate regressions for the three largest occupational groups separately and the results are presented in column 2-4 in Table 2 (men) and 3 (women).

Turning to the regressions that have been estimated separately by occupation, we find that temp agency workers in occupations that require a shorter university degree appear to have been experiencing the most adverse wage development. From a wage advantage of 9.6 percent (men) and 4.6 percent (women) in 2001 to a wage disadvantage of 21.0 percent (9.6$30.6=-21)$ among men and 16.7 percent $(4.6-21.3=-16.7)$ among women. The number of temp workers in this occupational group was very small in 2001 but has increased over time. Those who worked in the temp industry during the first part of our observation period might have been a highly selected group.

Machine operator is an occupation which has increased its share among temp agency workers much since 2001. One explanation for this is probably the signing of collective agreements between the blue-collar unions and the temp agency work industry facilitating hiring out blue-collar workers. The development of a temp agency wage gap among workers in this group is less dramatic than for other groups although there are indications of an increased wage gap also here.

In the beginning of the observation period office and customer service work was by far the largest occupational group within temp agencies but has declined in relative importance. For both men and women, there was not a negative wage gap in 2001 and for women, even a

\footnotetext{
${ }^{13}$ In 2001 there is missing information on occupation for $18.6 \%$ of the men and $12.2 \%$ for the women. In 2008 , the corresponding numbers are $11.3 \%$ and $6.5 \%$.
} 
small wage advantage. But as for the other groups, the wage gap seems to have been increasing over time.

Taking all these results together, it appears that wages in the temp agency sector have declined relative to wages in the labor market as a whole.

[TABLE $2 \& 3$ ABOUT HERE]

\section{Explaining the time trend in the temp agency wage gap}

In this section we discuss and test some hypotheses regarding why we have seen an increase in the temp agency wage gap. First, we analyze changes in the supply and demand for temp agency workers and its implication for wages in the sector; secondly we study changes in the returns to education; thirdly we investigate the possibility of decreasing entry wages; fourthly we analyze the wage growth for workers who exit and enter the temp agency sector; and finally we discuss the importance of collective agreements.

\section{Changes in the supply and the demand for temporary agency workers}

It is generally assumed that changes in the number of temp agency workers are driven by demand side changes and that temp agency employment varies procyclically. Hence, we would expect the share of temp agency workers to rise during an expansion and fall during a recession (Houseman et al. 2003).

In two papers Houseman et al. (2003) and de Graaf-Zijl and Berkhout (2007) discuss the relation between the tightness of the labor market, the demand for temp agency workers and temp agency wages. Since workers are assumed to prefer stability to flexibility, a permanent position will be chosen if available and temp agency work will in most cases only be chosen if there are no other options. Therefore, the temporary employment agencies will have difficulties in finding qualified personnel in tight labor markets and need to pay higher wages to attract workers. It might thus be interesting to see at the macro level how the level of 
unemployment is associated with the number of temp agency workers and the temp agency wage gap in Sweden during our period of observation.

Our first hypothesis to explain decreasing temp agency wages and an increasing temp agency wage gap is then that wages in the sector have in some way been affected by changes in the supply and demand for temp agency workers. The development of the total number of employees is presented in Figure 1. In the beginning of the observation period the sector was small and not very well known in Sweden and it was highly concentrated to the Stockholm area . High wages may therefore have been important to attract workers. In 2001, which is the year where we so far have observed the highest wages in the temp agency sector and a basically non-existent temp agency wage gap, unemployment was at its lowest in the period 2001-2008 (see Figure 5) (Eurostat, 2012).

During the period 2002-2005 unemployment in general and youth unemployment in particular, increased quite substantially (Eurostat, 2012). Youth unemployment can be particularly interesting to look at since the temp agency sector attracts a lot of young workers. During this period the temp agency wage gap increased the most while the number of temp agency workers essentially did not change. The three following years was characterized by a large increase in the number of temp agency workers, a decrease in unemployment and a wage gap that increased at a slower pace. The demand for temp agency workers hence appears to increase in good times and decrease in bad times, as we would expect. Even if temp agency wages were relatively high in 2001 when the labor market appears to have been tight and decreased the most between the years when unemployment increased the most (2003-2004) the development of temp agency wages after 2005 cannot as easily be explained within a supply-demand framework. Since the number employed by temp agencies increased and unemployment decreased we would expect increasing wages in the temp agency sector and hence a decreasing temp agency wage gap. Since this is not what we find, changes in the 
supply and demand for temp agency workers cannot provide us with the whole explanation for the increased temp agency wage gap.

There are, however, reasons to expect that the temp agency sector in Sweden did not follow the procyclical pattern suggested in the literature and wages did not develop in the predicted manner. For many who seek employment in the temp agency industry the wages offered might not be the main reason for seeking employment with a temp agency. Rather the prospect of getting employment at all may be the main factor. The industry attracts young workers and workers with foreign backgrounds, groups whose labor market experience from the Swedish labor market are limited and who could be judged by employers to be more risky workers. Hence it can be argued that the industry does not need to offer high wages to attract workers, but instead offers employment to groups that have difficulties in entering the labor market. Houseman et al. (2003) find that temp agency workers in auto supply companies receive lower compensation than regular employees and argue that temp agencies facilitates employers use of more risky workers in this way.

\section{Change in the returns to education}

We have seen that wages in the temp agency sector have decreased relative to overall wages in the economy. This development is not only found for one occupation but a general industry trend. Our second hypothesis is that there has been a decrease in the returns to education within the temp agency industry over time. It is possible that the level of qualifications of the jobs that firms outsource to temporary employment agencies has declined. Comparing the share of workers with higher education (short or long college education) in 2001 and 2008 it does not appear to have been a decrease in the share of highly educated workers, but rather the opposite. However, it is still possible that the level of qualifications of the jobs has decreased, given the educational level. Since we lack 
information on the exact level of qualifications for a job that is performed by the temp agency worker at the client firm, we try to assess whether this development is a likely explanation for the increased temp agency wage gap by investigating if there has been a change in the returns to education in the temp agency sector which differs from that in the whole labor market. In practice this is done by including interaction terms between temp agency work, year and education into the regression. By doing this we allow the return to education to differ by industry (temp/non-temp) and year.

In line with the results from the baseline model, the model with the interaction terms suggests that there is no significant wage differential in 2001. However, the estimates of the temp agency specific time trends are much smaller in absolute terms compared to the ones in the baseline model and in several cases the estimates are not significantly different from zero.

\section{[TABLE 4 ABOUT HERE]}

To be able to better understand why the inclusion of the interaction terms has such a large impact on the estimated temp agency wage gap, we estimate wage regression separately by year and for temp agency workers/non-temp agency workers. Doing this we find that the returns to higher education (level 5 and 6) in the temp agency sector decrease over time while the return to these levels of education in other sectors increase over time. This could mean that temp agencies value workers with a higher education less towards the end of the period. See Tables A3 and A4. ${ }^{14}$

We also estimate the temp agency wage gap separately by educational level and find an interesting pattern. The lower the level of education the larger was the wage gap in 2001, but the lower the level of education the smaller is the increase in the wage gap up to 2008. To get the total wage gap in 2008 we add the estimate for 2001 to the estimate for 2008 and find that

\footnotetext{
14 Regressions where years of schooling, instead of level of education, are entered linearly reveal that the return to schooling is persistently lower in the temp agency sector throughout the period. Consistent with the previous specification we find that return to schooling among temp agency workers decreases over time while the return to schooling in the rest of the labor market remains stable.
} 
the gap is smaller in 2008 for low educated workers than for highly educated workers. The overall pattern is similar for men and women but highly educated women go from a wage advantage of 8 percent in 2006 to a wage disadvantage of 20 percent in 2008 . The results from these regressions are presented in table A5 and A6.

Since the inclusion of interactions between temp agency work, year and education have a large impact on the estimates of how the temp agency gap has changed over time, a decrease in the return to higher education in the temp agency sector seems to be an important explanation for the increased temp agency wage gap.

One explanation for the low return to university education in the temp agency sector could be that employees with a university degree are not employed in occupations for which they are educated for. Younger workers who recently graduated from the university might accept a job which they are overqualified for while they are searching for a more permanent job. Immigrants, who are overrepresented among temp agency workers, have also been found to be overeducated to a higher extent than natives (Andersson Joona, Datta Gupta and Wadensjö 2011).

Using the so-called realized matches approach where the educational norm within each occupation is defined as mean years of schooling, plus/minus a one standard deviation, we have calculated the share of overeducated workers in the temp agency sector and in other sectors for each year 2001-2008. ${ }^{15}$ We find that the incidence of overeducation among temp agency workers was about 18 percent in 2001 and 20 percent in 2008 . The corresponding figures for workers in other sectors were 12 percent and 14 percent. The changes between 2001 and 2008 are hence small.

Another possible explanation for why temp agency workers with higher education are rewarded less for their education compared to highly educated workers who are employed in

\footnotetext{
${ }^{15}$ For an overview of the overeducation literature, see for example Leuven and Oosterbeek (2011).
} 
other sectors of the economy is that there might be a selection of less skilled highly educated workers into the temp agency sector. This idea could be tested through estimation of individual fixed effect models. Education is assumed to be constant over time. We therefore estimate the models separately by educational level and gender. The results from the OLS specification are compared to the fixed effect model and three specifications of each model are estimated: the first for the whole period, the second for the period 2001-2004, and the third for the period 2005-2008. The reason for estimating the gap separately for these two time periods is that in 2005 it became possible for temp agencies to employ workers with another main activity, such as students or retirees, on a temporary basis. This has led to that some temp agencies specialize in employing and hiring out young professionals to client firms on a more temporary basis. If there is a higher degree of (negative) selection among the highly educated in the last period we would expect to see a larger difference between the OLS and the FE-estimates, i.e. we would expect to find a less negative estimate in the FE-model for the period 2005-2008

The results from the above mentioned regressions do not provide us with a conclusive explanation for how the selection among high and low educated might differ. However, a number of other interesting things can be learnt from the regressions. First, as we found before, over the whole time period and over the observation period split into two periods, the temp agency gap increases with the level of education. It also increases over time and the increase in the wage gap is larger for those with higher education. This is basically what we learnt from the earlier estimations. Second, comparing the OLS and the FE-estimates in the first period to those in the second period for workers with higher education, it is apparent that individual unobservable time fixed effects explains less of the gap in the first period compared to the second period. During the first period, the difference between the OLS and the FE-estimates is very small, while the difference is larger in the second period. One 
explanation could be that selection explains very little of the temp agency wage gap during the period 2001-2004, while it is more important in 2005-2008. An alternative explanation is that the individuals who change to and from temp agency work and on whom the estimates are based, become more affected by such a change during the later period. Among highly educated, inter (between individuals) and intra (within individuals) personal comparisons of wages gives basically the same result. From the present FE-model we cannot determine whether the wages of workers entering or exiting the temp industry are affected the most. In section 4.3 we estimate wage growth models and find that both the gain from exiting the temp agency sector and the loss from entering it has increased over time (see table 8 and 9).

A third explanation is that the importance of time-varying unobserved variables has increased. Seniority could be one such variable. Seniority is positively correlated with wages and we know that the turnover in the temp industry is relatively high and hence the seniority lower than in other sectors. We do not have information on seniority in our data and it is not possible for us to calculate a measure since workers can fall out of the sample, not only because they change workplace but also because they are not included in the wage sample of the private sector all years.

[TABLE 5 \& 6 ABOUT HERE]

\section{Do entry wages decrease in the sector?}

The most elementary questions when it comes to explaining the increased temp agency wage gap is if it is due to (i) compositional changes of the workforce or (ii) if temp agencies in fact pay their employees lower wages. The first point was analyzed in the previous section and now we turn to the second. First we analyze changes in entry wages over time. If we find evidence of decreasing entry wages while controlling for a large set of background factors this could either be due to a decrease in unobservable productivity related factors or to that temp 
agencies pay lower wages to new employees.

The hypothesis of decreasing entry wages is tested by estimating a wage regression only for those entering the temp agency sector between two years. We find that entry wages for men were about 5.5 percent higher in 2005 than in 2002, while for women, entry wages in 2005 and 2006 were between 4.3 and 3.8 percent higher than in 2002. Overall, it does not appear to be a strong trend towards decreasing entry wages in the industry once we control for background factors such as age, education and occupation in the same year as entry wages are measured.

\section{[TABLE 6 ABOUT HERE]}

\section{Analyzing wage growth}

Another way of investigating if temp agencies pay lower wages to their employees is to analyze the wage growth for workers who stay in the industry for two consecutive years compared to the overall wage growth on the labor market during the same period.

By using data for two consecutive years we estimate the wage growth for (i) workers who start working in the temp industry, (ii) workers who quit working in the industry, and (iii) workers who stay in the industry in two consecutive years, in all three cases compared to the wage growth of those who do not work in the industry in any of the two years. Hence the model we estimate is:

$$
w_{i, t+1}-w_{i, t}=\alpha+\beta_{1} \text { bem }_{t+1}+\beta_{2} \text { bem }_{t}+\beta_{3}\left(\text { bem }_{t+1} * \text { bem }_{t}\right)
$$

$\beta_{1}$ is an estimate of the wage growth for workers who started working in the temp industry in period $t+1$, and $\beta_{2}$ is an estimate of the wage growth for those who left the industry between $t$ and $t+1$. In both cases compared with those who neither worked in the industry in period $t$ nor in period $t+1$. To get an estimate of the wage growth for those who are employed in the industry in both periods we need to add $\beta_{1}, \beta_{2}$, and $\beta_{3}$.

This regression is estimated for any two pairs of consecutive years from 2001 to 2008 . 
The idea is that a comparison of the different beta estimates across time can tell us something about how the returns to exiting and entering the temp industry have changed over time.

In the wage growth equation we also include controls for age, education, country of birth and change in the number of employees at the workplace.

For men we find that the average overall wage growth, measured by the intercept, is positive and fairly stable over time. In all years, the wage growth for those entering the temp industry, i.e. employed in the industry in period $t+1$ but employed elsewhere in period $t$, is lower than the overall wage growth and the difference in wage growth between those entering the industry and those who do not work in the industry in any of the periods increases. In 2002, male workers who entered the industry had a wage growth which was 2.7 percent lower, while it was 8 percent lower in 2008.

For women, however, in the beginning of the period wages for those entering the industry increased at a faster rate than overall wages and in some years there were no significant differences.

For those exiting the industry, the pattern is different. Already in 2001 the wage growth for those exiting a temp agency was higher than in the reference group and the reward for exiting the industry increases over time. Workers who left the temp agency sector between 2001 and 2002 experienced a 2.5 percent higher wage growth compared to the reference group while those who left the sector between 2007 and 2008 had an average wage growth which was 14.4 percent higher than the reference group. The fact that the wage gain from leaving the temp industry increases over time contradicts the idea of a more negative selection of workers into the industry towards the end of the observation period.

In sum, the results from these regressions indicate that the wage gain from leaving the industry has increased over time at the same time as the reduction in wages from starting in the industry has increased. It is possible that the outflow of high skilled, high paid workers 
increased at the same time as the inflow of low skilled, low paid workers increased. This means that it is not the temp sector in itself that causes these changes. The wage growth for those who stay in the sector for two consecutive years appears not to be so different from the wage increase for those who never enter the industry. This can be seen by adding the betacoefficients together. For most years the sum of them is very close to zero.

\section{[TABLE 8 \& 9 ABOUT HERE]}

\section{The collective agreements}

Before 2001 only white-collar trade unions had collective agreements with the temporary employment agencies employer association, Almega. In 2001 a collective agreement was also agreed upon by the different blue-collar (LO) unions and Almega. It meant that it became easier to hire out blue-collar workers and the temp agencies expanded in those occupations.

The agreement states that full-time work is the standard working time but that it is possible to reach agreements on the local level on part-time work. Special rules are valid for employing and hiring out those who have retired and want to combine pension and work and for students.

Wages are paid for contracted time irrespective of if the employee is hired out or not. For each employee an individual wage is decided that cannot be lower than the minimum wage stated in the agreement. The minimum wage differs according to skill level and age (the minimum wage is lower for young people. The wage should be at the same level as for those being employed at the workplace the temp is hired out to (but not lower than the minimum wage according to agreement). For hours not hired out while employed by the temp agency an hourly wage corresponding to 90 per cent of the average personal wage during the last three months is paid.

For white-collar workers there is a similar agreement regarding pay for hours not worked but the employee is ready to take on work immediately if contacted by the employment 
agency. The payment is considerably lower for those hours than for hours actually worked.

Hours not worked but contracted and the compensation for them are reported by the temporary employment agencies to Statistics Sweden but they are not included in the calculations of the monthly wage. ${ }^{16}$ By using information of the number of hours actual worked and the pay for those hours an hourly wage rate is calculated by Statistics Sweden. This wage rate is multiplied with the number of hours worked if full-time to get the individual monthly full-time wage which is presented in the statistics and used in our estimations. If the temporary employment agencies wage reports to Statistics Sweden are correct the monthly wage rate is a correct measure of wage paid for hours worked if working full-time.

Based on what we know about how the wage setting system for temp agency workers is regulated in the collective agreement and about how information on wages are collected by Statistics Swede, there is nothing that suggests that these factors should provide us with an explanation neither for the temp agency wage gap in itself, nor for the increase in the gap across time.

\section{Summary and conclusion}

Since temporary employment agencies were legalized in Sweden in the early 1990s there has been a worry that the conditions for temp agency workers are worse than those for workers in other sectors of the economy. In this paper we ask if there is a price for the flexibility that temporary employment agencies are assumed to have introduced to the labor market by analyzing the temp agency wage gap in Sweden between 1998 and 2008.

Our main finding is that a basically non-existent temp agency wage gap in 2001 has developed into a negative gap of almost 18 percent in 2008. The gap increases for both men and women and for the largest occupational groups among temps although the increase is smaller among less skilled workers and larger in more skilled occupations.

\footnotetext{
${ }^{16}$ Information in an e-mail from Marie Lidéus, Head of the unit for wage and labor costs statistics, Statistics Sweden, February 23, 2012.
} 
The main part of this paper is devoted to trying to explain this development. We do not find one single explanation for the increased wage gap between 2001 and 2008, but there are some clues as to how and why the wage gap has increased. Firstly, we find a small negative correlation between the total number of workers employed in the sector and the average wage using within county variation across time which would suggest that decreasing wages are associated with the supply of temp agency workers. However, when controls for the mean age among temp agency workers are included the correlation becomes insignificant.

Secondly and perhaps more importantly, we find that the return to higher education, relative to lower education, has decreased over time for temp agency workers while the return to higher education on the whole labor market remains stable during the observation period. When we control for a temp specific time trend in the return to education in the baseline model, the yearly estimates of the temp agency wage gap decreases both in absolute terms and relative to the gap in 2001. The lower returns to higher education among temps could be due to that temp agencies value higher education less towards the end of the period, a drop in the skill level given educational level, or that highly educated workers have become more negatively selected into the temp industry. The fact that the wage growth among those who leave the industry between two consecutive years is higher at the end of the period than at the beginning speaks against the hypothesis that the selection of workers into the industry has become more negative. Entry wages in the sector do not decrease over time in any systematic way.

Regressions with controls for individual fixed effects give mixed results across our observation period. The fixed effect regression for the period 2001-2004 gives an estimate of a male temp agency wage gap of 4 percent while the same model indicates a gap of almost 12 percent in the period 2005-2008. A consistent finding across time is that workers who enter the temp agency sector experience a drop in wages while workers who exit the sector 
experience an increase in wages as shown by the wage growth models. We do however find that the wage increase for those exiting the industry increases over time while the wage loss for those entering also increases but not to the same extent.

So is there a price for flexibility? One of the benefits from an increased temp agency sector is a certain amount of increased flexibility, primarily on behalf of the client firms. But there appears to be a price for this flexibility in terms of lower wages for temp agency workers. Several of the results presented in the paper indicate that temp agency workers receive higher wages once they leave the sector. Perhaps even more important is that the price of flexibility has increased over time. Although we have not been able to provide conclusive evidence of why this is the case, one of our main findings is that the return to higher education has decreased in the temp agency sector. 


\section{Tables and Figures}

Figure 1. Number of temp agency workers, 1998-2008 ${ }^{17}$

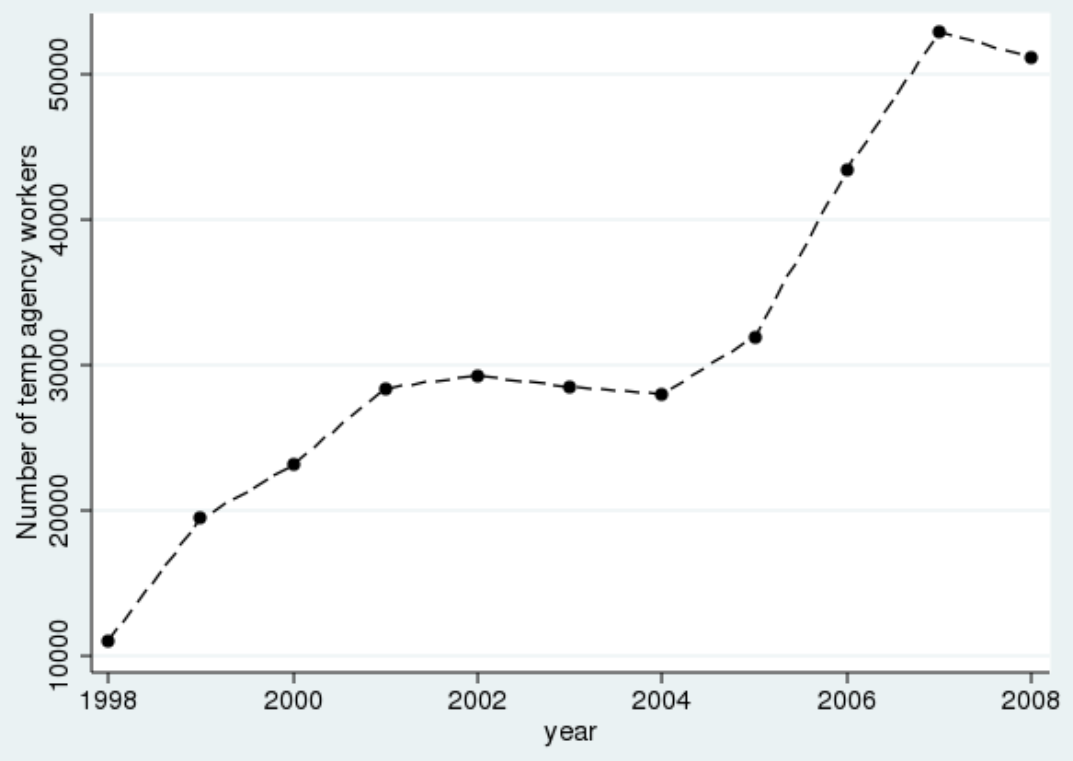

${ }^{17}$ This is the number of workers who were employed in the industry in November each year. For each year, the number that has received some income from the industry is larger. 
Figure 2 and 3. Development of monthly wages in temporary help agencies (THS) and other parts of the economy, men (1) and women 2b), 1998-2008.
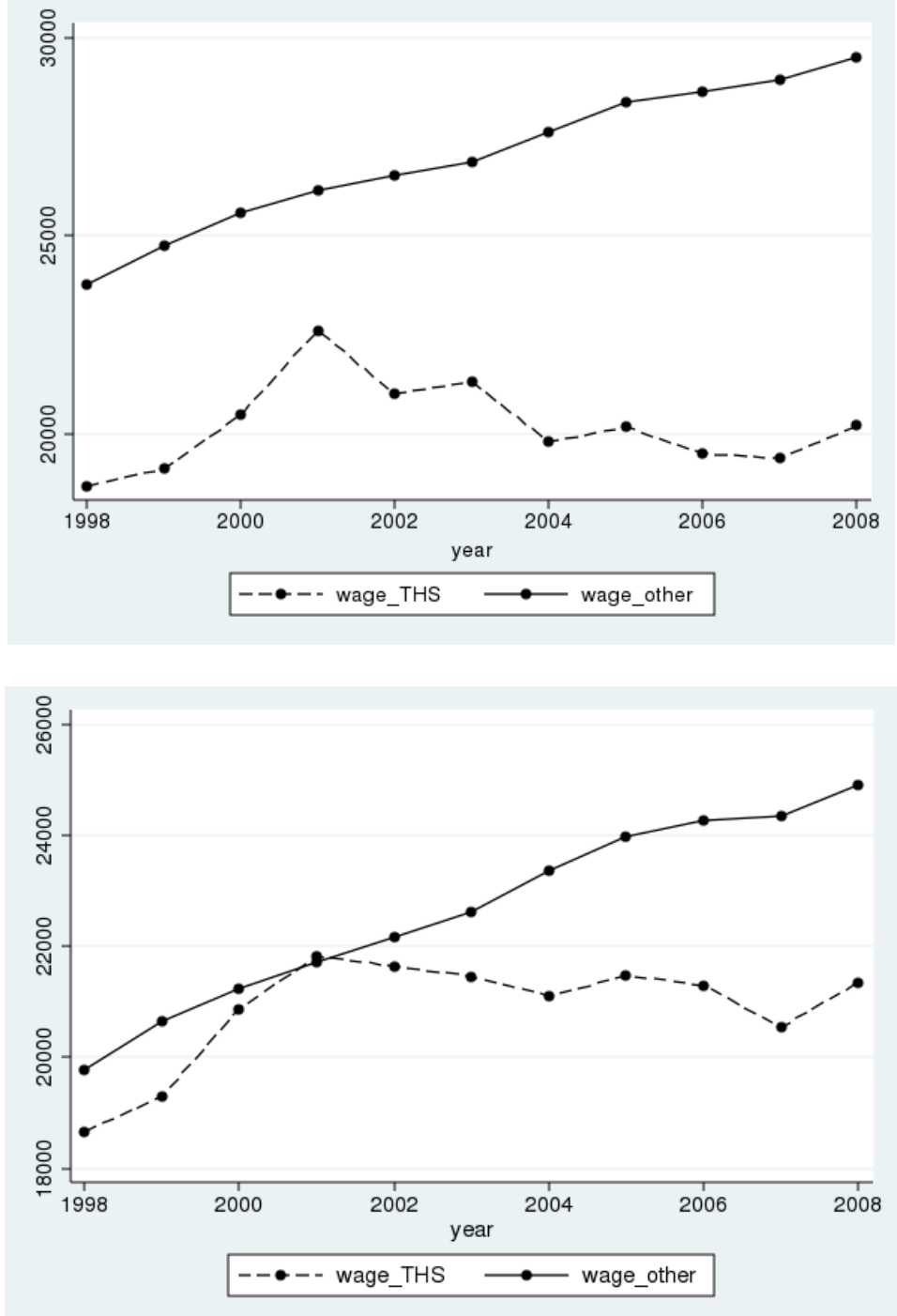
Figure 4. Development of monthly wages in temporary help agencies (THS) and other parts of the economy, men, 1998-2008. Medical doctors are excluded

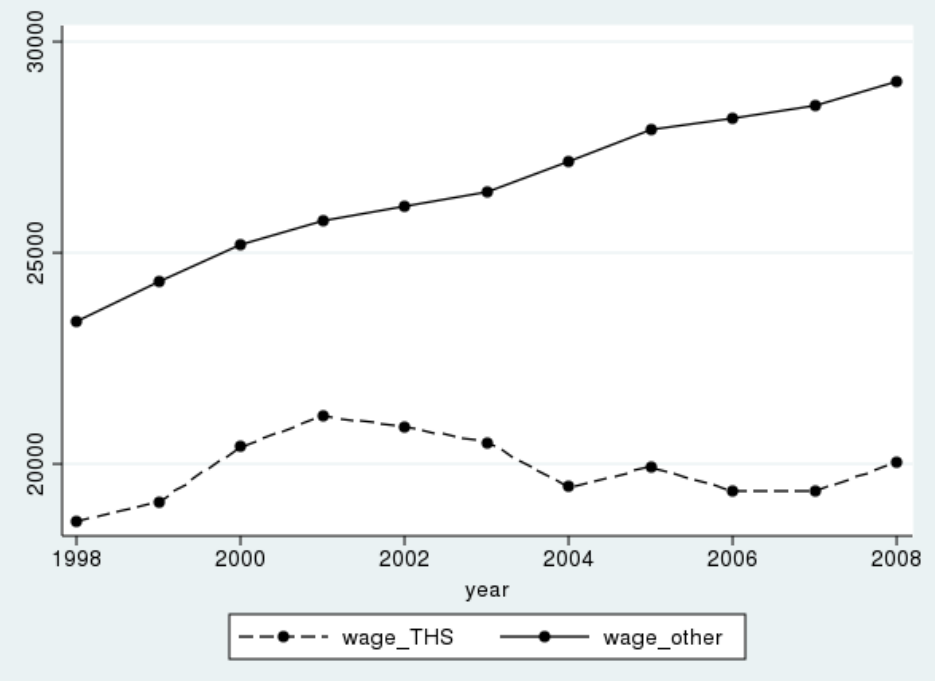

Figure 5. Total unemployment and youth unemployment, 2001-2008
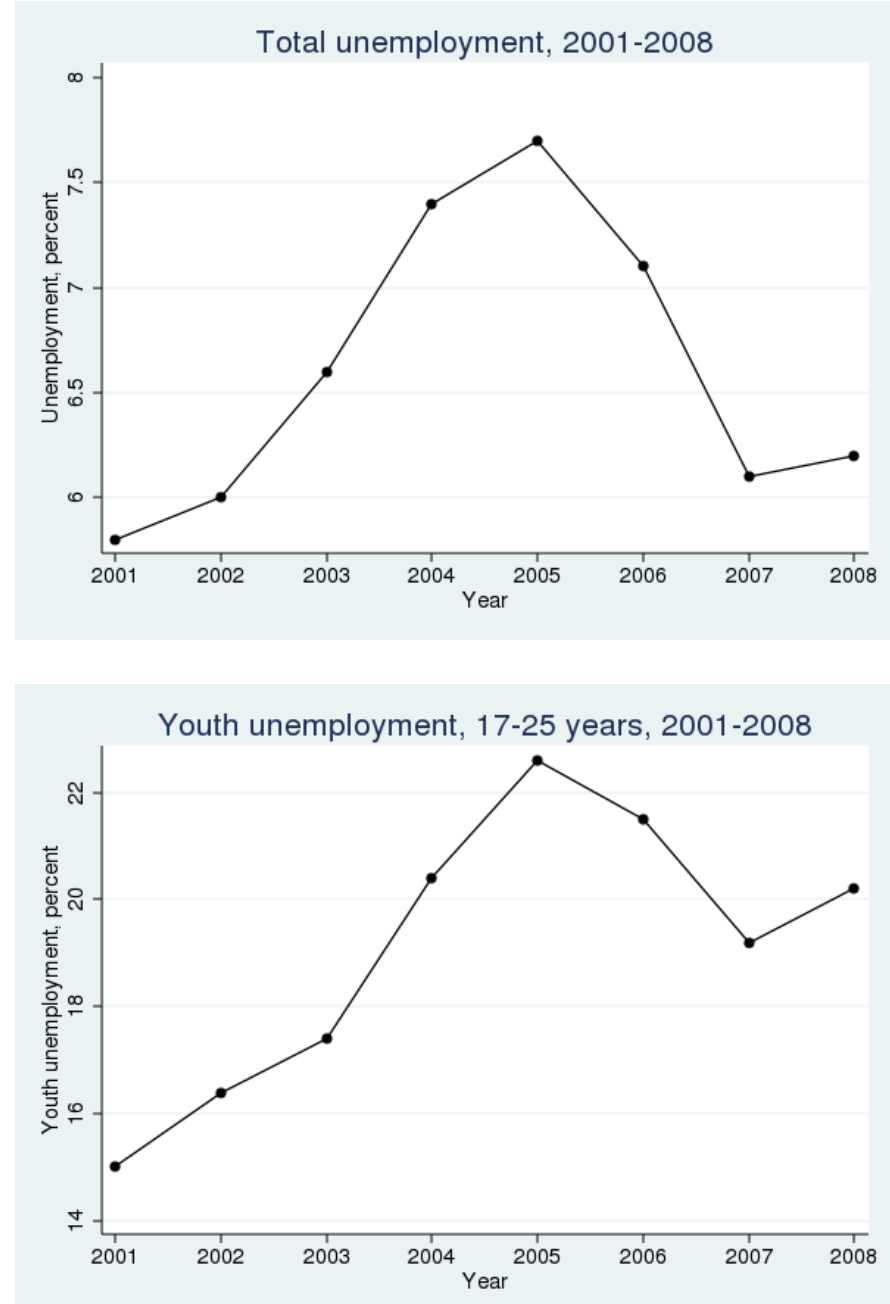
Table 1. Sample means for temp agency workers and employees in other industries, 2001 and 2008.

\begin{tabular}{|c|c|c|c|c|}
\hline & \multicolumn{2}{|c|}{2001} & \multicolumn{2}{|c|}{2008} \\
\hline & $\begin{array}{c}\text { Temp } \\
\text { worker }\end{array}$ & Other & $\begin{array}{c}\text { Temp } \\
\text { worker }\end{array}$ & Other \\
\hline Age (years) & 32.9 & 47.7 & 33.0 & 43.8 \\
\hline \multicolumn{5}{|l|}{ Age } \\
\hline $16-24$ & 25.9 & 6.1 & 27.0 & 5.9 \\
\hline $25-34$ & 37.2 & 21.2 & 36.1 & 18.6 \\
\hline $35-44$ & 19.9 & 26.0 & 20.1 & 26.7 \\
\hline $45-54$ & 12.0 & 28.1 & 10.8 & 26.2 \\
\hline 55 years and older & 5.1 & 18.6 & 6.0 & 22.6 \\
\hline Female & 63.3 & 52.7 & 46.9 & 54.7 \\
\hline \multicolumn{5}{|l|}{ Country of birth } \\
\hline Sweden, parents Sweden & 76.4 & 83.1 & 70.6 & 81.4 \\
\hline $\begin{array}{l}\text { Sweden, parents Western } \\
\text { immigrants }\end{array}$ & 6.5 & 4.6 & 5.6 & 5.0 \\
\hline $\begin{array}{l}\text { Sweden, parents non-Western } \\
\text { immigrants }\end{array}$ & 2.8 & 2.3 & 3.6 & 2.0 \\
\hline Western immigrants & 3.9 & 4.6 & 3.0 & 4.1 \\
\hline Non-Western immigrants & 10.4 & 5.4 & 17.2 & 7.6 \\
\hline \multicolumn{5}{|l|}{ Education } \\
\hline Primary school & 9.1 & 13.8 & 8.8 & 9.7 \\
\hline Upper secondary school & 60.4 & 48.5 & 53.5 & 46.0 \\
\hline Higher education & 29.9 & 37.4 & 36.8 & 44.0 \\
\hline \multicolumn{5}{|l|}{ Family } \\
\hline Married & 25.5 & 48.7 & 25.3 & 46.8 \\
\hline Children under the age of 7 & 17.4 & 16.1 & 18.3 & 17.6 \\
\hline Monthly wage, SEK & 21,227 & 23,503 & 20,554 & 26,670 \\
\hline Number of observations & 10,876 & $1,941,480$ & 17,777 & $1,972,509$ \\
\hline
\end{tabular}


Table 2. Temp agency wage gap 2001-2008, Men. Dependent variable is log wage.

\begin{tabular}{|c|c|c|c|c|}
\hline VARIABLES & All & $\begin{array}{l}\text { Office- and } \\
\text { customer } \\
\text { services }\end{array}$ & $\begin{array}{l}\text { Machine } \\
\text { operators }\end{array}$ & $\begin{array}{l}\text { Occupations } \\
\text { that require a } \\
\text { shorter } \\
\text { university } \\
\text { degree }\end{array}$ \\
\hline $\begin{array}{l}\text { Temp agency work } \\
\text { (in 2001) }\end{array}$ & $\begin{array}{c}0.007 \\
(0.005)\end{array}$ & $\begin{array}{c}0.005 \\
(0.006)\end{array}$ & $\begin{array}{c}-0.056^{* *} \\
(0.004)\end{array}$ & $\begin{array}{c}0.096^{* *} \\
(0.026)\end{array}$ \\
\hline \multicolumn{5}{|l|}{ Interactions } \\
\hline Temp agency*2002 & $\begin{array}{c}-0.052 * * \\
(0.006)\end{array}$ & $\begin{array}{c}-0.032 * * \\
(0.009)\end{array}$ & $\begin{array}{c}-0.026^{* *} \\
(0.006)\end{array}$ & $\begin{array}{l}-0.107 * * \\
(0.029)\end{array}$ \\
\hline Temp agency*2003 & $\begin{array}{c}-0.067 * * \\
(0.006)\end{array}$ & $\begin{array}{c}-0.084 * * \\
(0.008)\end{array}$ & $\begin{array}{c}-0.020 * * \\
(0.006)\end{array}$ & $\begin{array}{c}-0.143 * * \\
(0.030)\end{array}$ \\
\hline Temp agency*2004 & $\begin{array}{c}-0.125^{* *} \\
(0.005)\end{array}$ & $\begin{array}{c}-0.128 * * \\
(0.008)\end{array}$ & $\begin{array}{c}-0.070 * * \\
(0.005)\end{array}$ & $\begin{array}{c}-0.240 * * \\
(0.028)\end{array}$ \\
\hline Temp agency*2005 & $\begin{array}{c}-0.119 * * \\
(0.005)\end{array}$ & $\begin{array}{c}-0.144 * * \\
(0.009)\end{array}$ & $\begin{array}{c}-0.067 * * \\
(0.005)\end{array}$ & $\begin{array}{c}-0.196 * * \\
(0.028)\end{array}$ \\
\hline Temp agency*2006 & $\begin{array}{c}-0.149 * * \\
(0.005)\end{array}$ & $\begin{array}{c}-0.150 * * \\
(0.009)\end{array}$ & $\begin{array}{c}-0.123 * * \\
(0.005)\end{array}$ & $\begin{array}{c}-0.217 * * \\
(0.028)\end{array}$ \\
\hline Temp agency*2007 & $\begin{array}{c}-0.154^{* *} \\
(0.005)\end{array}$ & $\begin{array}{c}-0.170 * * \\
(0.008)\end{array}$ & $\begin{array}{c}-0.119 * * \\
(0.005)\end{array}$ & $\begin{array}{c}-0.243 * * \\
(0.027)\end{array}$ \\
\hline Temp agency*2008 & $\begin{array}{c}-0.187 * * \\
(0.005)\end{array}$ & $\begin{array}{c}-0.174 * * \\
(0.008)\end{array}$ & $\begin{array}{c}-0.118^{* *} \\
(0.005)\end{array}$ & $\begin{array}{c}-0.306^{* *} \\
(0.027)\end{array}$ \\
\hline Year dummies & & & & \\
\hline 2002 & $\begin{array}{l}0.014 * * \\
(0.000)\end{array}$ & $\begin{array}{c}0.016^{* *} \\
(0.001)\end{array}$ & $\begin{array}{l}0.010^{* *} \\
(0.000)\end{array}$ & $\begin{array}{l}0.012 * * \\
(0.001)\end{array}$ \\
\hline 2003 & $\begin{array}{l}0.025^{* *} \\
(0.000)\end{array}$ & $\begin{array}{c}0.033^{* *} \\
(0.001)\end{array}$ & $\begin{array}{l}0.020^{* *} \\
(0.000)\end{array}$ & $\begin{array}{l}0.023^{* *} \\
(0.001)\end{array}$ \\
\hline 2004 & $\begin{array}{l}0.047 * * \\
(0.000)\end{array}$ & $\begin{array}{c}0.054 * * \\
(0.001)\end{array}$ & $\begin{array}{l}0.042 * * \\
(0.000)\end{array}$ & $\begin{array}{l}0.050^{* *} \\
(0.001)\end{array}$ \\
\hline 2005 & $\begin{array}{l}0.071 * * \\
(0.000)\end{array}$ & $\begin{array}{c}0.085^{* *} \\
(0.001)\end{array}$ & $\begin{array}{l}0.074 * * \\
(0.000)\end{array}$ & $\begin{array}{l}0.072 * * \\
(0.001)\end{array}$ \\
\hline 2006 & $\begin{array}{l}0.083^{* *} \\
(0.000)\end{array}$ & $\begin{array}{l}0.100^{* *} \\
(0.001)\end{array}$ & $\begin{array}{l}0.089 * * \\
(0.000)\end{array}$ & $\begin{array}{l}0.084 * * \\
(0.001)\end{array}$ \\
\hline 2007 & $\begin{array}{l}0.089 * * \\
(0.000)\end{array}$ & $\begin{array}{c}0.097 * * \\
(0.001)\end{array}$ & $\begin{array}{l}0.100^{* *} \\
(0.000)\end{array}$ & $\begin{array}{l}0.097 * * \\
(0.001)\end{array}$ \\
\hline 2008 & $\begin{array}{l}0.096^{* *} \\
(0.000)\end{array}$ & $\begin{array}{c}0.104 * * \\
(0.001)\end{array}$ & $\begin{array}{l}0.105^{* *} \\
(0.000)\end{array}$ & $\begin{array}{l}0.105^{* *} \\
(0.001)\end{array}$ \\
\hline Constant & $\begin{array}{l}9.433^{* *} \\
(0.001) \\
\end{array}$ & $\begin{array}{l}9.270 * * \\
(0.003) \\
\end{array}$ & $\begin{array}{l}9.638^{* *} \\
(0.002)\end{array}$ & $\begin{array}{c}9.034^{* *} \\
(0.003)\end{array}$ \\
\hline Number of observations & $7,266,165$ & 460,230 & $1,294,041$ & $1,469,350$ \\
\hline R-squared & 0.650 & 0.368 & 0.322 & 0.397 \\
\hline$\%$ with temp agency work & 0.5 & 1.9 & 1.0 & 0.3 \\
\hline
\end{tabular}


Table 3. Temp agency wage gap 2001-2008, women. Dependent variable is log wage. Parttime workers are excluded

\begin{tabular}{|c|c|c|c|c|}
\hline VARIABLES & All & $\begin{array}{c}\text { Office and } \\
\text { customer } \\
\text { services }\end{array}$ & $\begin{array}{l}\text { Occupations } \\
\text { that require } \\
\text { special } \\
\text { theoretical } \\
\text { knowledge }\end{array}$ & $\begin{array}{c}\text { Occupations } \\
\text { that require a } \\
\text { shorter } \\
\text { university } \\
\text { degree }\end{array}$ \\
\hline $\begin{array}{l}\text { Temp agency work } \\
\text { in } 2001\end{array}$ & $\begin{array}{l}0.032 * * \\
(0.002)\end{array}$ & $\begin{array}{l}0.008 * * \\
(0.002)\end{array}$ & $\begin{array}{c}-0.092 * * \\
(0.019)\end{array}$ & $\begin{array}{c}0.046^{* *} \\
(0.013)\end{array}$ \\
\hline Interactions & & & & \\
\hline Temp agency*2002 & $\begin{array}{c}-0.027 * * \\
(0.003)\end{array}$ & $\begin{array}{c}-0.030 * * \\
(0.003)\end{array}$ & $\begin{array}{l}0.019 * * \\
(0.000)\end{array}$ & $\begin{array}{l}-0.008 \\
(0.015)\end{array}$ \\
\hline Temp agency*2003 & $\begin{array}{c}-0.068 * * \\
(0.003)\end{array}$ & $\begin{array}{c}-0.048 * * \\
(0.003)\end{array}$ & $\begin{array}{l}0.033^{* * *} \\
(0.000)\end{array}$ & $\begin{array}{c}-0.103 * * \\
(0.014)\end{array}$ \\
\hline Temp agency*2004 & $\begin{array}{c}-0.122 * * \\
(0.003)\end{array}$ & $\begin{array}{c}-0.096 * * \\
(0.003)\end{array}$ & $\begin{array}{l}0.049 * * \\
(0.000)\end{array}$ & $\begin{array}{c}-0.148^{* *} \\
(0.014)\end{array}$ \\
\hline Temp agency*2005 & $\begin{array}{c}-0.138 * * \\
(0.003)\end{array}$ & $\begin{array}{c}-0.119 * * \\
(0.004)\end{array}$ & $\begin{array}{l}0.067 * * \\
(0.000)\end{array}$ & $\begin{array}{c}-0.144 * * \\
(0.014)\end{array}$ \\
\hline Temp agency*2006 & $\begin{array}{c}-0.161 * * \\
(0.003)\end{array}$ & $\begin{array}{c}-0.137 * * \\
(0.004)\end{array}$ & $\begin{array}{l}0.077 * * \\
(0.000)\end{array}$ & $\begin{array}{c}-0.168^{* *} \\
(0.014)\end{array}$ \\
\hline Temp agency*2007 & $\begin{array}{c}-0.181 * * \\
(0.003)\end{array}$ & $\begin{array}{c}-0.167 * * \\
(0.003)\end{array}$ & $\begin{array}{c}0.082 * * \\
(0.000)\end{array}$ & $\begin{array}{c}-0.238 * * \\
(0.014)\end{array}$ \\
\hline Temp agency*2008 & $\begin{array}{c}-0.189 * * \\
(0.003)\end{array}$ & $\begin{array}{c}-0.160 * * \\
(0.003)\end{array}$ & $\begin{array}{c}0.087 * * \\
(0.000)\end{array}$ & $\begin{array}{c}-0.213 * * \\
(0.014)\end{array}$ \\
\hline \multicolumn{5}{|l|}{ Year dummies } \\
\hline 2002 & $\begin{array}{l}0.018 * * \\
(0.000)\end{array}$ & $\begin{array}{c}0.018^{* *} \\
(0.000)\end{array}$ & $\begin{array}{l}0.069 * * \\
(0.024)\end{array}$ & $\begin{array}{l}0.018^{* *} \\
(0.000)\end{array}$ \\
\hline 2003 & $\begin{array}{c}0.033 * * \\
(0.000)\end{array}$ & $\begin{array}{c}0.032 * * \\
(0.000)\end{array}$ & $\begin{array}{c}0.031 \\
(0.024)\end{array}$ & $\begin{array}{l}0.033 * * \\
(0.000)\end{array}$ \\
\hline 2004 & $\begin{array}{c}0.059 * * \\
(0.000)\end{array}$ & $\begin{array}{l}0.056^{* *} \\
(0.000)\end{array}$ & $\begin{array}{c}0.021 \\
(0.022)\end{array}$ & $\begin{array}{l}0.057 * * \\
(0.000)\end{array}$ \\
\hline 2005 & $\begin{array}{l}0.081 * * \\
(0.000)\end{array}$ & $\begin{array}{l}0.082 * * \\
(0.000)\end{array}$ & $\begin{array}{c}0.007 \\
(0.023)\end{array}$ & $\begin{array}{l}0.077 * * \\
(0.000)\end{array}$ \\
\hline 2006 & $\begin{array}{c}0.092 * * \\
(0.000)\end{array}$ & $\begin{array}{c}0.096^{* *} \\
(0.000)\end{array}$ & $\begin{array}{l}-0.028 \\
(0.021)\end{array}$ & $\begin{array}{l}0.092 * * \\
(0.000)\end{array}$ \\
\hline 2007 & $\begin{array}{c}0.092 * * \\
(0.000)\end{array}$ & $\begin{array}{c}0.104 * * \\
(0.001)\end{array}$ & $\begin{array}{c}-0.059 * * \\
(0.021)\end{array}$ & $\begin{array}{l}0.101^{* *} \\
(0.000)\end{array}$ \\
\hline 2008 & $\begin{array}{c}0.108 * * \\
(0.000)\end{array}$ & $\begin{array}{c}0.111^{* *} \\
(0.001)\end{array}$ & $\begin{array}{c}-0.109 * * \\
(0.021)\end{array}$ & $\begin{array}{l}0.106^{* * *} \\
(0.000)\end{array}$ \\
\hline Number of observations & $8,445,297$ & $1,106,326$ & $1,850,815$ & $2,116,325$ \\
\hline R-squared & 0.641 & 0.350 & 0.477 & 0.393 \\
\hline$\%$ with temp agency work & 0.6 & 3.0 & 0.2 & 0.6 \\
\hline
\end{tabular}

Note: All models include controls for age, age squared, education, marital status, number of children, country of birth, county or residence, student status, number of employees at the workplace and occupation on a three-digit level. Robust standard errors in parentheses. ${ }^{*} \mathrm{p}<0.01,{ }^{*} \mathrm{p}<0.05$, Women in public sector working less than $75 \%$ of full-time are excluded. 
Table 4.Temp agency wage gap 2001-2008. Dependent variable is log wage.

\begin{tabular}{|c|c|c|c|c|}
\hline \multirow[b]{2}{*}{ VARIABLES } & \multicolumn{2}{|c|}{ Men } & \multicolumn{2}{|c|}{ Women } \\
\hline & I & II & I & II \\
\hline $\begin{array}{l}\text { Temp agency work } \\
\text { in } 2001\end{array}$ & $\begin{array}{c}0.007 \\
(0.005)\end{array}$ & $\begin{array}{l}-0.033 \\
(0.022)\end{array}$ & $\begin{array}{l}0.051 * * \\
(0.004)\end{array}$ & $\begin{array}{c}0.008 \\
(0.026)\end{array}$ \\
\hline Interactions & & & & \\
\hline Temp agency*2002 & $\begin{array}{c}-0.052 * * \\
(0.006)\end{array}$ & $\begin{array}{l}-0.042 \\
(0.029)\end{array}$ & $\begin{array}{c}-0.042 * * \\
(0.005)\end{array}$ & $\begin{array}{l}-0.035 \\
(0.033)\end{array}$ \\
\hline Temp agency*2003 & $\begin{array}{c}-0.067 * * \\
(0.006)\end{array}$ & $\begin{array}{l}-0.025 \\
(0.029)\end{array}$ & $\begin{array}{c}-0.060 * * \\
(0.005)\end{array}$ & $\begin{array}{l}-0.026 \\
(0.033)\end{array}$ \\
\hline Temp agency*2004 & $\begin{array}{c}-0.125^{* *} \\
(0.005)\end{array}$ & $\begin{array}{l}-0.061^{*} \\
(0.030)\end{array}$ & $\begin{array}{c}-0.131 * * \\
(0.005)\end{array}$ & $\begin{array}{l}-0.047 \\
(0.039)\end{array}$ \\
\hline Temp agency*2005 & $\begin{array}{c}-0.119 * * \\
(0.005)\end{array}$ & $\begin{array}{l}-0.015 \\
(0.028)\end{array}$ & $\begin{array}{c}-0.105 * * \\
(0.005)\end{array}$ & $\begin{array}{c}0.001 \\
(0.038)\end{array}$ \\
\hline Temp agency*2006 & $\begin{array}{c}-0.149 * * \\
(0.005)\end{array}$ & $\begin{array}{l}-0.033 \\
(0.027)\end{array}$ & $\begin{array}{c}-0.124 * * \\
(0.005)\end{array}$ & $\begin{array}{l}-0.059 \\
(0.041)\end{array}$ \\
\hline Temp agency*2007 & $\begin{array}{c}-0.154 * * \\
(0.005)\end{array}$ & $\begin{array}{l}-0.046 \\
(0.025)\end{array}$ & $\begin{array}{c}-0.163 * * \\
(0.004)\end{array}$ & $\begin{array}{c}-0.098^{* *} \\
(0.034)\end{array}$ \\
\hline Temp agency*2008 & $\begin{array}{c}-0.187 * * \\
(0.005)\end{array}$ & $\begin{array}{l}-0.058^{*} \\
(0.025)\end{array}$ & $\begin{array}{c}-0.203^{* *} \\
(0.004)\end{array}$ & $\begin{array}{l}-0.064^{*} \\
(0.030)\end{array}$ \\
\hline Year dummies & & & & \\
\hline 2002 & $\begin{array}{l}0.014^{* *} \\
(0.000)\end{array}$ & $\begin{array}{l}0.012^{* *} \\
(0.001)\end{array}$ & $\begin{array}{c}0.017 * * \\
(0.000)\end{array}$ & $\begin{array}{c}0.013 * * \\
(0.001)\end{array}$ \\
\hline 2003 & $\begin{array}{l}0.025^{* *} \\
(0.000)\end{array}$ & $\begin{array}{l}0.028^{* *} \\
(0.001)\end{array}$ & $\begin{array}{l}0.033^{* *} \\
(0.000)\end{array}$ & $\begin{array}{l}0.031 * * \\
(0.001)\end{array}$ \\
\hline 2004 & $\begin{array}{l}0.047 * * \\
(0.000)\end{array}$ & $\begin{array}{c}0.053 * * \\
(0.001)\end{array}$ & $\begin{array}{c}0.058^{* *} \\
(0.000)\end{array}$ & $\begin{array}{c}0.060^{* *} \\
(0.001)\end{array}$ \\
\hline 2005 & $\begin{array}{l}0.071 * * \\
(0.000)\end{array}$ & $\begin{array}{l}0.082 * * \\
(0.001)\end{array}$ & $\begin{array}{l}0.080^{* *} \\
(0.000)\end{array}$ & $\begin{array}{l}0.087 * * \\
(0.001)\end{array}$ \\
\hline 2006 & $\begin{array}{l}0.083 * * \\
(0.000)\end{array}$ & $\begin{array}{l}0.095^{* *} \\
(0.001)\end{array}$ & $\begin{array}{c}0.092 * * \\
(0.000)\end{array}$ & $\begin{array}{l}0.100^{* *} \\
(0.001)\end{array}$ \\
\hline 2007 & $\begin{array}{l}0.089 * * \\
(0.000)\end{array}$ & $\begin{array}{l}0.106^{* *} \\
(0.001)\end{array}$ & $\begin{array}{l}0.093 * * \\
(0.000)\end{array}$ & $\begin{array}{l}0.098 * * \\
(0.001)\end{array}$ \\
\hline 2008 & $\begin{array}{l}0.096 * * \\
(0.000)\end{array}$ & $\begin{array}{l}0.119 * * \\
(0.001)\end{array}$ & $\begin{array}{l}0.107 * * \\
(0.000)\end{array}$ & $\begin{array}{l}0.125^{* *} \\
(0.001)\end{array}$ \\
\hline Constant & $\begin{array}{c}9.433 * * \\
(0.001)\end{array}$ & $\begin{array}{c}9.338^{* *} \\
(0.001)\end{array}$ & $\begin{array}{c}9.405^{* *} \\
(0.001)\end{array}$ & $\begin{array}{c}9.343 * * \\
(0.001)\end{array}$ \\
\hline Temp*Year*Education & No & Yes & No & Yes \\
\hline Number of observations & $7,266,165$ & $7,266,165$ & $7,999,678$ & $7,999,678$ \\
\hline R-squared & 0.650 & 0.650 & 0.647 & 0.647 \\
\hline
\end{tabular}


Table 5. Temp agency wage gap by educational level. OLS and individual fixed effect estimates. Men

\begin{tabular}{|c|c|c|c|c|c|c|}
\hline \multirow[t]{2}{*}{ Educational level } & \multicolumn{2}{|c|}{ All years, 2001-2008 } & \multicolumn{2}{|c|}{$2001-2004$} & \multicolumn{2}{|c|}{$2005-2008$} \\
\hline & OLS & FE & OLS & FE & OLS & FE \\
\hline $\mathrm{All}^{\mathrm{a}}$ & $\begin{array}{c}-0.124 * * \\
(0.001)\end{array}$ & $\begin{array}{c}-0.096^{* *} \\
(0.001)\end{array}$ & $\begin{array}{c}-0.061 * * \\
(0.002)\end{array}$ & $\begin{array}{c}-0.042 * * \\
(0.003)\end{array}$ & $\begin{array}{c}-0.151^{* *} \\
(0.001)\end{array}$ & $\begin{array}{c}-0.117 * * \\
(0.002)\end{array}$ \\
\hline Observations & \multicolumn{2}{|c|}{$7,266,165$} & \multicolumn{2}{|c|}{$3,609,360$} & \multicolumn{2}{|c|}{$3,656,805$} \\
\hline $\begin{array}{l}\text { Primary school } \\
\text { less than } 9 \text { years }\end{array}$ & $\begin{array}{c}-0.120^{* *} \\
(0.005)\end{array}$ & $\begin{array}{c}-0.083^{* *} \\
(0.008)\end{array}$ & $\begin{array}{c}-0.103 * * \\
(0.008)\end{array}$ & $\begin{array}{c}-0.047 * * \\
(0.013)\end{array}$ & $\begin{array}{c}-0.128 * * \\
(0.006)\end{array}$ & $\begin{array}{c}-0.096^{* *} \\
(0.010)\end{array}$ \\
\hline Observations & \multicolumn{2}{|c|}{322,779} & \multicolumn{2}{|c|}{192,711} & \multicolumn{2}{|c|}{130,068} \\
\hline $\begin{array}{c}\text { Primary school } \\
9(10) \text { years }\end{array}$ & $\begin{array}{l}-0.119 * * \\
(0.003)\end{array}$ & $\begin{array}{c}-0.095 * * \\
(0.003)\end{array}$ & $\begin{array}{c}-0.066^{* *} \\
(0.005)\end{array}$ & $\begin{array}{c}-0.049 * * \\
(0.006)\end{array}$ & $\begin{array}{c}-0.144 * * \\
(0.003)\end{array}$ & $\begin{array}{c}-0.118^{* *} \\
(0.004)\end{array}$ \\
\hline Observations & \multicolumn{2}{|c|}{669.008} & \multicolumn{2}{|c|}{339,358} & \multicolumn{2}{|c|}{329,650} \\
\hline $\begin{array}{l}\text { Upper secondary } 2 \\
\text { years or less }\end{array}$ & $\begin{array}{c}-0.134 * * \\
(0.002)\end{array}$ & $\begin{array}{c}-0.105^{* *} \\
(0.003)\end{array}$ & $\begin{array}{c}-0.071^{* *} \\
(0.004)\end{array}$ & $\begin{array}{c}-0.046^{* *} \\
(0.004)\end{array}$ & $\begin{array}{c}-0.167 * * \\
(0.002)\end{array}$ & $\begin{array}{c}-0.140 * * \\
(0.003)\end{array}$ \\
\hline Observations & \multicolumn{2}{|c|}{$1,923,634$} & 991,400 & & \multicolumn{2}{|c|}{932,234} \\
\hline $\begin{array}{l}\text { Upper secondary } \\
\text { more than } 2 \text { years }\end{array}$ & $\begin{array}{c}-0.121 * * \\
(0.001)\end{array}$ & $\begin{array}{c}-0.093 * * \\
(0.002)\end{array}$ & $\begin{array}{c}-0.055^{* *} \\
(0.003)\end{array}$ & $\begin{array}{c}-0.038 * * \\
(0.003)\end{array}$ & $\begin{array}{c}-0.148 * * \\
(0.002)\end{array}$ & $\begin{array}{c}-0.119 * * \\
(0.002)\end{array}$ \\
\hline Observations & \multicolumn{2}{|c|}{$1,538,210$} & \multicolumn{2}{|c|}{741,468} & \multicolumn{2}{|c|}{796,742} \\
\hline $\begin{array}{l}\text { Higher education } \\
\text { less than } 3 \text { years }\end{array}$ & $\begin{array}{c}-0.128^{* *} \\
(0.003)\end{array}$ & $\begin{array}{c}-0.109^{* *} \\
(0.005)\end{array}$ & $\begin{array}{c}-0.056^{* *} \\
(0.006)\end{array}$ & $\begin{array}{c}-0.062^{* *} \\
(0.008)\end{array}$ & $\begin{array}{c}-0.160 * * \\
(0.003)\end{array}$ & $\begin{array}{c}-0.130 * * \\
(0.007)\end{array}$ \\
\hline Observations & \multicolumn{2}{|c|}{$1,150,939$} & \multicolumn{2}{|c|}{563,255} & \multicolumn{2}{|c|}{587,684} \\
\hline $\begin{array}{l}\text { Higher education } 3 \\
\text { years or more }\end{array}$ & $\begin{array}{c}-0.158 * * \\
(0.004)\end{array}$ & $\begin{array}{c}-0.111^{* *} \\
(0.004)\end{array}$ & $\begin{array}{c}-0.094 * * \\
(0.006)\end{array}$ & $\begin{array}{c}-0.089^{* *} \\
(0.010)\end{array}$ & $\begin{array}{c}-0.190 * * \\
(0.004)\end{array}$ & $\begin{array}{c}-0.123 * * \\
(0.005)\end{array}$ \\
\hline Observations & \multicolumn{2}{|c|}{$1,504,403$} & \multicolumn{2}{|c|}{704,728} & \multicolumn{2}{|c|}{799,675} \\
\hline
\end{tabular}

${ }^{a}$ Workers with post-graduate education are excluded. 
Table 6. Temp agency wage gap by educational level. OLS and individual fixed effect estimates. Women

\begin{tabular}{|c|c|c|c|c|c|c|}
\hline \multirow[t]{2}{*}{ Educational level } & \multicolumn{2}{|c|}{ All years, 2001-2008 } & \multicolumn{2}{|c|}{$2001-2004$} & \multicolumn{2}{|c|}{$2005-2008$} \\
\hline & OLS & FE & OLS & FE & OLS & FE \\
\hline $\mathrm{All}^{\mathrm{a}}$ & $\begin{array}{c}-0.066^{* *} \\
(0.001)\end{array}$ & $\begin{array}{c}-0.051^{* *} \\
(0.001)\end{array}$ & $\begin{array}{c}-0.005^{* *} \\
(0.002)\end{array}$ & $\begin{array}{l}-0.003 \\
(0.002)\end{array}$ & $\begin{array}{c}-0.110^{* *} \\
(0.001)\end{array}$ & $\begin{array}{c}-0.080^{* *} \\
(0.002)\end{array}$ \\
\hline Observations & \multicolumn{2}{|c|}{$7,999,678$} & \multicolumn{2}{|c|}{$3,941,525$} & \multicolumn{2}{|c|}{$4,058,153$} \\
\hline $\begin{array}{l}\text { Primary school } \\
\text { less than } 9 \text { years }\end{array}$ & $\begin{array}{c}-0.030^{* *} \\
(0.008)\end{array}$ & $\begin{array}{l}-0.012 \\
(0.010)\end{array}$ & $\begin{array}{l}-0.008 \\
(0.012)\end{array}$ & $\begin{array}{l}-0.005 \\
(0.014)\end{array}$ & $\begin{array}{c}-0.047 * * \\
(0.010)\end{array}$ & $\begin{array}{l}-0.022 \\
(0.014)\end{array}$ \\
\hline Observations & \multicolumn{2}{|c|}{232,917} & \multicolumn{2}{|c|}{141,193} & \multicolumn{2}{|c|}{91,724} \\
\hline $\begin{array}{c}\text { Primary school } \\
9(10) \text { years }\end{array}$ & $\begin{array}{c}-0.067 * * \\
(0.003)\end{array}$ & $\begin{array}{c}-0.052^{* *} \\
(0.005)\end{array}$ & $\begin{array}{c}-0.035^{* *} \\
(0.004)\end{array}$ & $\begin{array}{c}-0.026^{* *} \\
(0.006)\end{array}$ & $\begin{array}{c}-0.091^{* *} \\
(0.004)\end{array}$ & $\begin{array}{c}-0.072 * * \\
(0.007)\end{array}$ \\
\hline Observations & \multicolumn{2}{|c|}{522.128} & \multicolumn{2}{|c|}{276,870} & \multicolumn{2}{|c|}{245,258} \\
\hline $\begin{array}{l}\text { Upper secondary } 2 \\
\text { years or less }\end{array}$ & $\begin{array}{c}-0.052 * * \\
(0.002)\end{array}$ & $\begin{array}{c}-0.049 * * \\
(0.003)\end{array}$ & $\begin{array}{c}-0.011^{* *} \\
(0.003)\end{array}$ & $\begin{array}{l}-0.008 \\
(0.004)\end{array}$ & $\begin{array}{c}-0.089^{* *} \\
(0.003)\end{array}$ & $\begin{array}{c}-0.069 * * \\
(0.004)\end{array}$ \\
\hline Observations & \multicolumn{2}{|c|}{$2,272,250$} & \multicolumn{2}{|c|}{$1,190,178$} & \multicolumn{2}{|c|}{$1,082,072$} \\
\hline $\begin{array}{l}\text { Upper secondary } \\
\text { more than } 2 \text { years }\end{array}$ & $\begin{array}{c}-0.070 * * \\
(0.002)\end{array}$ & $\begin{array}{c}-0.057 * * \\
(0.002)\end{array}$ & $\begin{array}{c}-0.023 * * \\
(0.002)\end{array}$ & $\begin{array}{c}-0.017 * * \\
(0.003)\end{array}$ & $\begin{array}{c}-0.103 * * \\
(0.002)\end{array}$ & $\begin{array}{c}-0.080 * * \\
(0.003)\end{array}$ \\
\hline Observations & \multicolumn{2}{|c|}{$1,399,943$} & \multicolumn{2}{|c|}{658,739} & \multicolumn{2}{|c|}{741,204} \\
\hline $\begin{array}{l}\text { Higher education } \\
\text { less than } 3 \text { years }\end{array}$ & $\begin{array}{c}-0.056^{* *} \\
(0.003)\end{array}$ & $\begin{array}{c}-0.045^{* *} \\
(0.004)\end{array}$ & $\begin{array}{c}0.019 * * \\
(0.004)\end{array}$ & $\begin{array}{c}0.002 \\
(0.005)\end{array}$ & $\begin{array}{c}-0.114 * * \\
(0.003)\end{array}$ & $\begin{array}{c}-0.087 * * \\
(0.005)\end{array}$ \\
\hline Observations & \multicolumn{2}{|c|}{$1,366,842$} & \multicolumn{2}{|c|}{685,194} & \multicolumn{2}{|c|}{681,648} \\
\hline $\begin{array}{l}\text { Higher education } 3 \\
\text { years or more }\end{array}$ & $\begin{array}{c}-0.096^{* *} \\
(0.003)\end{array}$ & $\begin{array}{c}-0.064^{* *} \\
(0.003)\end{array}$ & $\begin{array}{l}0.009^{*} \\
(0.004)\end{array}$ & $\begin{array}{l}-0.011^{*} \\
(0.005)\end{array}$ & $\begin{array}{c}-0.156^{* *} \\
(0.003)\end{array}$ & $\begin{array}{c}-0.103 * * \\
(0.004)\end{array}$ \\
\hline Observations & \multicolumn{2}{|c|}{$2,140,353$} & \multicolumn{2}{|c|}{959,311} & \multicolumn{2}{|c|}{$1,181,042$} \\
\hline
\end{tabular}

${ }^{\mathrm{a}}$ Workers with post-graduate education are excluded 
Table 7. Entry wages in the temp agency workers, 2002-2008.

\begin{tabular}{lcc}
\hline Year & \multicolumn{2}{c}{ Ln(wage) } \\
& Men & Women \\
\hline 2002 & reference & reference \\
2003 & -0.007 & -0.016 \\
& $(0.013)$ & $(0.010)$ \\
2004 & -0.007 & -0.014 \\
2005 & $(0.014)$ & $(0.011)$ \\
& $0.056^{* *}$ & $0.043^{* *}$ \\
2006 & $(0.014)$ & $(0.012)$ \\
2007 & 0.022 & $0.038^{* *}$ \\
& $(0.014)$ & $(0.011)$ \\
2008 & -0.019 & -0.009 \\
& $(0.013)$ & $(0.010)$ \\
Constant & -0.025 & $-0.027^{* *}$ \\
& $(0.013)$ & $(0.010)$ \\
Number of observations & $9.723 * *$ & $9.514^{* *}$ \\
R-squared & $(0.047)$ & $(0.044)$ \\
\hline
\end{tabular}

Note: All models include controls for age, age squared, education, marital status, number of children, country of birth, county or residence, student status, number of employees at the workplace and occupation on a three-digit level. Robust standard errors in parentheses. ${ }^{* *} \mathrm{p}<0.01,{ }^{*} \mathrm{p}<0.05$ 
Table 8. Wage growth. Men

\begin{tabular}{|c|c|c|c|c|c|c|c|}
\hline & $2002 \& 2001$ & $2003 \& 2002$ & $2004 \& 2003$ & $2005 \& 2004$ & $2006 \& 2005$ & $2007 \& 2006$ & $2008 \& 2007$ \\
\hline $\begin{array}{l}\text { Temp agency work } \text { t }_{t+1} \\
\left(\beta_{1}\right)\end{array}$ & $\begin{array}{c}-0.027^{*} \\
(0.011)\end{array}$ & $\begin{array}{l}-0.021^{*} \\
(0.009)\end{array}$ & $\begin{array}{c}-0.047 * * \\
(0.009)\end{array}$ & $\begin{array}{c}-0.025^{* *} \\
(0.007)\end{array}$ & $\begin{array}{c}-0.059 * * \\
(0.009)\end{array}$ & $\begin{array}{c}-0.078 * * \\
(0.006)\end{array}$ & $\begin{array}{c}-0.080^{* *} \\
(0.012)\end{array}$ \\
\hline $\begin{array}{l}\text { Temp agency work } \mathrm{t} \\
\left(\beta_{2}\right)\end{array}$ & $\begin{array}{l}0.025^{* *} \\
(0.007)\end{array}$ & $\begin{array}{c}0.047 * * \\
(0.006)\end{array}$ & $\begin{array}{c}0.059 * * \\
(0.006)\end{array}$ & $\begin{array}{c}0.077 * * \\
(0.006)\end{array}$ & $\begin{array}{c}0.105^{* *} \\
(0.005)\end{array}$ & $\begin{array}{c}0.163 * * \\
(0.004)\end{array}$ & $\begin{array}{c}0.144 * * \\
(0.004)\end{array}$ \\
\hline $\begin{array}{l}\text { Temp agency work } \mathrm{t}_{\mathrm{t}+1} * \\
\text { Temp agency work } \mathrm{t}_{\mathrm{t}}\left(\beta_{3}\right)\end{array}$ & $\begin{array}{l}-0.034^{*} \\
(0.014)\end{array}$ & $\begin{array}{l}-0.018 \\
(0.012)\end{array}$ & $\begin{array}{l}-0.011 \\
(0.012)\end{array}$ & $\begin{array}{c}-0.036 * * \\
(0.009)\end{array}$ & $\begin{array}{c}-0.052 * * \\
(0.011)\end{array}$ & $\begin{array}{c}-0.074 * * \\
(0.008)\end{array}$ & $\begin{array}{c}-0.056^{* *} \\
(0.013)\end{array}$ \\
\hline Constant $(\alpha)$ & $\begin{array}{c}0.011^{* *} \\
(0.000)\end{array}$ & $\begin{array}{c}0.013^{* *} \\
(0.000)\end{array}$ & $\begin{array}{c}0.023 * * \\
(0.000)\end{array}$ & $\begin{array}{c}0.025 * * \\
(0.000)\end{array}$ & $\begin{array}{c}0.017 * * \\
(0.000)\end{array}$ & $\begin{array}{c}0.009 * * \\
(0.000)\end{array}$ & $\begin{array}{c}0.012 * * \\
(0.000)\end{array}$ \\
\hline $\begin{array}{l}\text { Number of observations } \\
\text { R-squared }\end{array}$ & $\begin{array}{c}761,289 \\
0.006\end{array}$ & $\begin{array}{c}773,380 \\
0.002\end{array}$ & $\begin{array}{c}775,239 \\
0.003\end{array}$ & $\begin{array}{c}770,329 \\
0.003\end{array}$ & $\begin{array}{c}758,472 \\
0.007\end{array}$ & $\begin{array}{c}769,647 \\
0.013\end{array}$ & $\begin{array}{c}754,593 \\
0.011\end{array}$ \\
\hline
\end{tabular}

Note: With additional controls. Robust standard errors in parentheses. $* * \mathrm{p}<0.01, * \mathrm{p}<0.05$. Workers at firms with zero employees are excluded.

Table 9. Wage growth. Women

\begin{tabular}{|c|c|c|c|c|c|c|c|}
\hline & $2002 \& 2001$ & $2003 \& 2002$ & $2004 \& 2003$ & $2005 \& 2004$ & $2006 \& 2005$ & $2007 \& 2006$ & $2008 \& 2007$ \\
\hline $\begin{array}{l}\text { Temp agency work } \mathrm{w}_{\mathrm{t}+1} \\
\left(\beta_{1}\right)\end{array}$ & $\begin{array}{c}0.028 * * \\
(0.007)\end{array}$ & $\begin{array}{l}-0.010 \\
(0.008)\end{array}$ & $\begin{array}{l}-0.018^{*} \\
(0.009)\end{array}$ & $\begin{array}{c}0.014 \\
(0.008)\end{array}$ & $\begin{array}{c}0.012 \\
(0.008)\end{array}$ & $\begin{array}{c}-0.025^{* *} \\
(0.006)\end{array}$ & $\begin{array}{c}-0.057 * * \\
(0.006)\end{array}$ \\
\hline $\begin{array}{l}\text { Temp agency work } \mathrm{w}_{\mathrm{t}} \\
\left(\beta_{2}\right)\end{array}$ & $\begin{array}{l}0.012 * * \\
(0.005)\end{array}$ & $\begin{array}{c}0.016 * * \\
(0.005)\end{array}$ & $\begin{array}{l}0.028 * * \\
(0.005)\end{array}$ & $\begin{array}{c}0.060 * * \\
(0.006)\end{array}$ & $\begin{array}{c}0.086 * * \\
(0.005)\end{array}$ & $\begin{array}{l}0.150 * * \\
(0.005)\end{array}$ & $\begin{array}{l}0.147 * * \\
(0.004)\end{array}$ \\
\hline $\begin{array}{l}\text { Temp agency work } \mathrm{t}_{\mathrm{t}+1} * \\
\text { Temp agency work }_{\mathrm{t}}\left(\beta_{3}\right)\end{array}$ & $\begin{array}{c}-0.091 * * \\
(0.009)\end{array}$ & $\begin{array}{l}-0.011 \\
(0.009)\end{array}$ & $\begin{array}{l}-0.019 \\
(0.010)\end{array}$ & $\begin{array}{c}-0.050 * * \\
(0.010)\end{array}$ & $\begin{array}{c}-0.104 * * \\
(0.010)\end{array}$ & $\begin{array}{c}-0.144 * * \\
(0.009)\end{array}$ & $\begin{array}{c}-0.070 * * \\
(0.008)\end{array}$ \\
\hline Constant $(\alpha)$ & $\begin{array}{l}0.014 * * \\
(0.000)\end{array}$ & $\begin{array}{l}0.017 * * \\
(0.000)\end{array}$ & $\begin{array}{l}0.029 * * \\
(0.000)\end{array}$ & $\begin{array}{l}0.024 * * \\
(0.000)\end{array}$ & $\begin{array}{l}0.017 * * \\
(0.000)\end{array}$ & $\begin{array}{c}-0.004 * * \\
(0.000)\end{array}$ & $\begin{array}{l}0.031 * * \\
(0.000)\end{array}$ \\
\hline $\begin{array}{l}\text { Number of observations } \\
\text { R-squared }\end{array}$ & $\begin{array}{c}947,306 \\
0.008\end{array}$ & $\begin{array}{c}963,219 \\
0.002\end{array}$ & $\begin{array}{c}968,221 \\
0.001\end{array}$ & $\begin{array}{c}968,573 \\
0.003\end{array}$ & $\begin{array}{c}964,587 \\
0.006\end{array}$ & $\begin{array}{c}999,338 \\
0.026\end{array}$ & $\begin{array}{c}1,006,636 \\
0.015\end{array}$ \\
\hline
\end{tabular}

Note: With additional controls. Robust standard errors in parentheses. ${ }^{* *} \mathrm{p}<0.01,{ }^{*} \mathrm{p}<0.05$. Workers at firms with zero employees are excluded. 


\section{References}

Amuedo-Dorantes, Catalina. 2008. The Role of Temporary Help Agency Employment on Temp-to-Perm Transitions. Journal of Labor Research, 29(2): 138-161.

Andersson, Fredrik, Harry J. Holzer and Julia Lane. 2009. Temporary Help Agencies and the Advancement Prospects of Low Earners. In David H. Autor (Ed.), Studies of Labor Market Intermediation, Chicago: The University of Chicago Press.

Andersson, Pernilla and Eskil Wadensjö. 2004. Statistik om bemanningsbranschen. Presentation och jämförelser av två nya databaser, Working Paper SOFI 6/2004.

Andersson Joona, Pernilla, Nabanita Datta Gupta and Eskil Wadensjö. 2011. Under- and overeducation among immigrants in Sweden: A knotty tale. Unpublished paper

Antoni, Manfred and Elke Jahn. 2009. Do Changes in Regulation Affect Employment Duration in Temporary Help Agencies? Industrial and Labor Relations Review, 62(2): 226-251.

Autor, David. 2001. Why do Temporary Help Firms Provide Free General Skills Training? Quarterly Journal of Economics, 116(4): 1409-1448.

Bemanningsföretagen (Almega). 2010a. Arbetare. Avtal för bemanningsföretag, [Workers: Collective agreement with 14 LO-unions] (validity: 2010-11-01-2012-04-30).

Bemanningsföretagen (Almega), Unionen (TCO) and Akademikerförbunden (SACO). 2010b. Allmänna anställningsvillkor. Avtal för tjänstemän, [General working conditions. Collecitve agreement for white-collar workers] (validity: 2010-05-01-2012-04-30).

Bemanningsföretagen (Almega) Unionen and Akademikerförbunden. 2010c. Löneavtal. Tjänstemän i bemanningsföretag. [Wage agreement. White-collar workers in the temporary employment agencies] (validity: 2010-11-01-2012-04-30).

Böheim, René and Ana Rute Cardoso. 2009. Temporary Help Services Employment in Portugal, 1995-2000. In David H. Autor (Ed.), Studies of Labor Market Intermediation, Chicago: The University of Chicago Press.

De Graaf-Zijl, Marloes and Ernest E. Berkhout. 2007. Temporary agency work and the business cycle. International journal of Manpower, 28(7): 539-556.

Eurostat, http://epp.eurostat.ec.europa.eu/portal/page/portal/eurostat/home/, 2012-03-26

Friberg, Kent, Åsa Olli and Eskil Wadensjö. 1999. Privata arbetsförmedlingar och personaluthyrningsföretag i Sverige. Stockholm: Swedish Institute for Social Research.

Fabiano, Bruno, Fabio Currò, Andrea P. Reverberi and Renato Pastorino. 2008. A statistical study on temporary work and occupational accidents: Specific risk factors and risk management strategies. Safety Science, 46(23): 535-544.

Forde, Chris and Gary Slater. 2005. Agency Work in Britain: Character, Consequences and Regulation. British Journal of Industrial Relations, 43(2): 249-271. 
Heinrich, Carolyn J., Peter R. Mueser and Kenneth R. Troske. 2009. The Role of Temporary Help Employment in Low-Wage Worker Advancement. In David H. Autor (Ed.), Studies of Labor Market Intermediation, Chicago: The University of Chicago Press.

Houseman, Susan N., Arne L. Kalleberg and George A. Erickcek. 2003. The Role of Temporary Agency Employment in Tight Labor Markets. Industrial and Labor Relations Review, 57(1): 105-127.

Ichino, Andrea, Fabrizia Mealli and Tommaso Nannicini. 2008. From temporary help jobs to permanent employment: what can we learn from matching estimators and their sensitivity? Journal of Applied Econometrics, 23(3): 305-327.

Jahn, Elke and Jan Bentzen. 2010. What Drives the Demand for Temporary Agency Workers? IZA Discussion Paper No. 5333.

Jahn, Elke and Michael Rosholm. 2010. Looking Beyond the Bridge: How Temporary Agency Employment Affects Labor Market Outcomes. IZA Discussion Paper No. 4973.

Jahn, Elke and Dario Pozzoli. 2011. Does the Sector Experience Affect the Pay Gap for the Temporary Agency Workers. IZA Discussion Paper No. 5837.

Jahn, Elke. 2010. Reassessing the Wage Penalty for Temps in Germany. Journal of Economics and Statistics, 230(2): 208-233.

Jahn, Elke. 2010a. The Structure of the Temp Wage Gap in Slack Labor Markets. Working paper, University of Aarhus.

Johnson, Anders. 2010. Hyrt går hem. Historien om den svenska bemanningsbranschen, Stockholm: Bemanningsföretagen and Informationsförlaget.

Kvasnicka, Michael. 2009. Does Temporary Help Work Provide a Stepping Stone to Regular Employment? In David H. Autor (Ed.), Studies of Labor Market Intermediation, Chicago: The University of Chicago Press.

Kvasnicka, Michael and Axel Werwatz. 2002. On the Wages of Temporary Help Service Workers in Germany. Discussion Paper No. 70, SFB 373, Humboldt Universität, Berlin.

Leuven, Edwin and Hessel Oosterbeek. 2011. Overeducation and Mismatch in the Labor market. In Erik Hanushek, Stephen Machin and Ludger Woessman (Eds.): Handbook of the Economics of Education, Vol. 4, pp. 283-326. North Holland: Elsevier.

Rosen, Sherwin. 1986. The Theory of Equalizing Differences. In Orley Ashenfelter and Richard Layard (Eds.), Handbook of Labor Economics, Vol. I, pp. 641-692. North-Holland: Elsevier

Segal, Lewis and Daniel Sullivan. 1998. Wage Differentials for Temporary Services Work:

Evidence from Administrative Data. Federal Reserve Bank of Chicago, Working Paper Series, No. WP-98-23.

Wadensjö, Eskil (1990), "Privata arbetsförmedlingar" in SOU 1990:31, Perspektiv på arbetsförmedlingen. 


\section{Appendix}

Table A1. Share of workers defined as "moving personnel".

\begin{tabular}{lccc}
\hline Moving personnel & Temp agency & Other (private) & Other (public) \\
\hline 2001 & 44.7 & 4.1 & 6.5 \\
2002 & 31.2 & 3.4 & 7.0 \\
2003 & 33.9 & 3.5 & 6.8 \\
2004 & 32.2 & 3.7 & 7.1 \\
2005 & 36.7 & 3.8 & 6.9 \\
2006 & 41.3 & 4.3 & 8.5 \\
2007 & 34.7 & 4.3 & 8.5 \\
2008 & 15.5 & 4.3 & 8.4 \\
\hline
\end{tabular}

Table A2. Number of male medical doctors in temporary help agencies 1998-2008 (and as percent of all male employees in the sector within parentheses)

\begin{tabular}{cc}
\hline Year & $\begin{array}{c}\text { Male medical doctors in temporary help } \\
\text { agencies (and as percent of all men employed in } \\
\text { the sector) }\end{array}$ \\
\hline 1998 & 0 \\
1999 & 0 \\
2000 & $3(0.07)$ \\
2001 & $104(2.6)$ \\
2002 & $53(1.3)$ \\
2003 & $87(1.9)$ \\
2004 & $26(0.5)$ \\
2005 & $42(0.2)$ \\
2006 & $15(0.2)$ \\
2007 & $4(0.04)$ \\
2008 & $25(0.23)$ \\
\hline
\end{tabular}

Note. Only those with wage information are included. 
Table A3. Return to education by year and temp agency sector/non-temp agency. Men

\begin{tabular}{|c|c|c|c|c|c|c|c|c|}
\hline VARIABLES & $\begin{array}{c}2002 \\
\text { Temp } \\
\text { agency }\end{array}$ & $\begin{array}{l}2001 \\
\text { Other }\end{array}$ & $\begin{array}{c}2002 \\
\text { Temp } \\
\text { agency }\end{array}$ & $\begin{array}{l}2002 \\
\text { Other }\end{array}$ & $\begin{array}{c}2003 \\
\text { Temp } \\
\text { agency }\end{array}$ & $\begin{array}{l}2003 \\
\text { Other }\end{array}$ & $\begin{array}{c}2004 \\
\text { Temp } \\
\text { agency }\end{array}$ & $\begin{array}{l}2004 \\
\text { Other }\end{array}$ \\
\hline $\begin{array}{l}\text { Primary school less } \\
\text { than } 9 \text { years }\end{array}$ & \multicolumn{8}{|c|}{ REFERENCE } \\
\hline $\begin{array}{l}\text { Primary school } \\
9(10) \text { years }\end{array}$ & $\begin{array}{c}0.032 \\
(0.024)\end{array}$ & $\begin{array}{c}0.038 * * \\
(0.001)\end{array}$ & $\begin{array}{l}0.035 \\
(0.021)\end{array}$ & $\begin{array}{r}0.037 * * \\
(0.001)\end{array}$ & $\begin{array}{c}0.022 \\
(0.019)\end{array}$ & $\begin{array}{r}0.039 * * \\
(0.001)\end{array}$ & $\begin{array}{l}0.049 * \\
(0.019)\end{array}$ & $\begin{array}{r}0.040 * * \\
(0.001)\end{array}$ \\
\hline $\begin{array}{l}\text { Upper secondary } 2 \\
\text { years or less }\end{array}$ & $\begin{array}{c}0.027 \\
(0.023)\end{array}$ & $\begin{array}{l}0.054 * * \\
(0.001)\end{array}$ & $\begin{array}{c}0.032 \\
(0.019)\end{array}$ & $\begin{array}{l}0.052 * * \\
(0.001)\end{array}$ & $\begin{array}{c}0.018 \\
(0.018)\end{array}$ & $\begin{array}{l}0.052 * * \\
(0.001)\end{array}$ & $\begin{array}{l}0.044^{*} \\
(0.019)\end{array}$ & $\begin{array}{c}0.053 * * \\
(0.001)\end{array}$ \\
\hline $\begin{array}{l}\text { Upper secondary } \\
\text { more than } 2 \text { year }\end{array}$ & $\begin{array}{c}0.068 * * \\
(0.023)\end{array}$ & $\begin{array}{l}0.092 * * \\
(0.001)\end{array}$ & $\begin{array}{l}0.064 * * \\
(0.020)\end{array}$ & $\begin{array}{c}0.093 * * \\
(0.001)\end{array}$ & $\begin{array}{c}0.049 * * \\
(0.018)\end{array}$ & $\begin{array}{c}0.096 * * \\
(0.001)\end{array}$ & $\begin{array}{c}0.057 * * \\
(0.018)\end{array}$ & $\begin{array}{c}0.103 * * \\
(0.001)\end{array}$ \\
\hline $\begin{array}{l}\text { Higher education } \\
\text { less than } 3 \text { years }\end{array}$ & $\begin{array}{c}0.092 * * \\
(0.025)\end{array}$ & $\begin{array}{l}0.138 * * \\
(0.001)\end{array}$ & $\begin{array}{l}0.077 * * \\
(0.021)\end{array}$ & $\begin{array}{l}0.137 * * \\
(0.001)\end{array}$ & $\begin{array}{l}0.052^{* *} \\
(0.020)\end{array}$ & $\begin{array}{l}0.134 * * \\
(0.001)\end{array}$ & $\begin{array}{l}0.057 * * \\
(0.020)\end{array}$ & $\begin{array}{l}0.137 * * \\
(0.001)\end{array}$ \\
\hline $\begin{array}{l}\text { Higher education } 3 \\
\text { years or more }\end{array}$ & $\begin{array}{c}0.140 * * \\
(0.028)\end{array}$ & $\begin{array}{c}0.223 * * \\
(0.001)\end{array}$ & $\begin{array}{l}0.127 * * \\
(0.023)\end{array}$ & $\begin{array}{l}0.220 * * \\
(0.001)\end{array}$ & $\begin{array}{l}0.090^{* *} \\
(0.021)\end{array}$ & $\begin{array}{l}0.212 * * \\
(0.001)\end{array}$ & $\begin{array}{l}0.061 * * \\
(0.021)\end{array}$ & $\begin{array}{c}0.216^{* *} \\
(0.001)\end{array}$ \\
\hline $\begin{array}{l}\text { Post graduate } \\
\text { education }\end{array}$ & $\begin{array}{l}0.159 \\
(0.092)\end{array}$ & $\begin{array}{c}0.397 * * \\
(0.003)\end{array}$ & $\begin{array}{c}0.034 \\
(0.061)\end{array}$ & $\begin{array}{r}0.397 * * \\
(0.002)\end{array}$ & $\begin{array}{c}-0.204 * * \\
(0.023)\end{array}$ & $\begin{array}{c}0.382 * * \\
(0.002)\end{array}$ & $\begin{array}{c}0.527 * * \\
(0.145)\end{array}$ & $\begin{array}{r}0.385^{* *} \\
(0.002)\end{array}$ \\
\hline Missing value & $\begin{array}{l}0.071^{*} \\
(0.033)\end{array}$ & $\begin{array}{c}0.143^{* *} \\
(0.005)\end{array}$ & $\begin{array}{l}0.081^{*} \\
(0.041)\end{array}$ & $\begin{array}{c}0.168 * * \\
(0.006)\end{array}$ & $\begin{array}{c}0.124 \\
(0.074)\end{array}$ & $\begin{array}{c}0.164 * * \\
(0.006)\end{array}$ & $\begin{array}{c}0.107 * * \\
(0.031)\end{array}$ & $\begin{array}{c}0.171 * * \\
(0.006)\end{array}$ \\
\hline Constant & $\begin{array}{c}9.301 * * \\
(0.064)\end{array}$ & $\begin{array}{c}9.355^{* *} \\
(0.003)\end{array}$ & $\begin{array}{c}9.407 * * \\
(0.059)\end{array}$ & $\begin{array}{c}9.385 * * \\
(0.003)\end{array}$ & $\begin{array}{c}9.435^{* *} \\
(0.059)\end{array}$ & $\begin{array}{c}9.390 * * \\
(0.003)\end{array}$ & $\begin{array}{c}9.547 * * \\
(0.052)\end{array}$ & $\begin{array}{c}9.397 * * \\
(0.003)\end{array}$ \\
\hline $\begin{array}{l}\text { Number of observations } \\
\text { R-squared }\end{array}$ & $\begin{array}{l}2,326 \\
0,607\end{array}$ & $\begin{array}{c}886,728 \\
0.645\end{array}$ & $\begin{array}{l}2,793 \\
0,614\end{array}$ & $\begin{array}{c}905,226 \\
0.650\end{array}$ & $\begin{array}{c}3,231 \\
0.624\end{array}$ & $\begin{array}{r}902,582 \\
0,654\end{array}$ & $\begin{array}{l}3,605 \\
0,661\end{array}$ & $\begin{array}{c}902,869 \\
0,641\end{array}$ \\
\hline
\end{tabular}

Note: All models include age, age squared, marital status, number of children, country of birth, county or residence, student status, number of employees at the workplace and occupation on a three-digit level. Robust standard errors in parentheses. ${ }^{* *} \mathrm{p}<0.01,{ }^{*} \mathrm{p}<0.05$ 
Table A3 continued. Return to education by year and temp agency sector/non-temp agency. Men

\begin{tabular}{lcccccccc}
\hline VARIABLES & $\begin{array}{c}2005 \\
\text { Temp } \\
\text { agency }\end{array}$ & $\begin{array}{c}2005 \\
\text { Other }\end{array}$ & $\begin{array}{c}2006 \\
\text { Temp } \\
\text { agency }\end{array}$ & $\begin{array}{c}2006 \\
\text { Other }\end{array}$ & $\begin{array}{c}2007 \\
\text { Temp } \\
\text { agency }\end{array}$ & $\begin{array}{c}2007 \\
\text { Other }\end{array}$ & $\begin{array}{c}2008 \\
\text { Temp } \\
\text { agency }\end{array}$ & $\begin{array}{c}2008 \\
\text { Other }\end{array}$ \\
\hline $\begin{array}{l}\text { Primary school less than } 9 \\
\text { years }\end{array}$ & & & & REFERENCE & & \\
Primary school & 0.027 & $0.037^{* *}$ & 0.005 & $0.036^{* *}$ & 0.011 & $0.034^{* *}$ & 0.016 & $0.030^{* *}$ \\
9(10) years & $(0.017)$ & $(0.001)$ & $(0.016)$ & $(0.001)$ & $(0.011)$ & $(0.001)$ & $(0.009)$ & $(0.001)$ \\
Upper secondary 2 & 0.022 & $0.051^{* *}$ & -0.006 & $0.050^{* *}$ & 0.005 & $0.047^{* *}$ & 0.017 & $0.042^{* *}$ \\
years or less & $(0.016)$ & $(0.001)$ & $(0.015)$ & $(0.001)$ & $(0.011)$ & $(0.001)$ & $(0.009)$ & $(0.001)$ \\
Upper secondary & $0.043^{* *}$ & $0.105^{* *}$ & 0.009 & $0.106^{* *}$ & 0.019 & $0.103^{* *}$ & $0.034^{* *}$ & $0.102^{* *}$ \\
more than 2 year & $(0.016)$ & $(0.001)$ & $(0.015)$ & $(0.001)$ & $(0.011)$ & $(0.001)$ & $(0.009)$ & $(0.001)$ \\
Higher education & $0.040^{*}$ & $0.137^{* *}$ & -0.002 & $0.135^{* *}$ & 0.017 & $0.134^{* *}$ & $0.031^{* *}$ & $0.125^{* *}$ \\
less than 3 years & $(0.018)$ & $(0.001)$ & $(0.016)$ & $(0.001)$ & $(0.012)$ & $(0.001)$ & $(0.010)$ & $(0.001)$ \\
Higher education 3 & $0.063^{* *}$ & $0.211^{* *}$ & $0.049^{* *}$ & $0.210^{* *}$ & $0.064^{* *}$ & $0.208^{* *}$ & $0.066^{* *}$ & $0.194^{* *}$ \\
years or more & $(0.020)$ & $(0.001)$ & $(0.017)$ & $(0.001)$ & $(0.013)$ & $(0.001)$ & $(0.011)$ & $(0.001)$ \\
Post graduate & 0.069 & $0.374^{* *}$ & $0.369^{* *}$ & $0.376^{* *}$ & $0.278^{* *}$ & $0.372^{* *}$ & $0.213^{* *}$ & $0.352^{* *}$ \\
education & $(0.090)$ & $(0.002)$ & $(0.080)$ & $(0.002)$ & $(0.049)$ & $(0.002)$ & $(0.065)$ & $(0.002)$ \\
Missing value & 0.015 & $0.160^{* *}$ & 0.042 & $0.160^{* *}$ & $-0.037^{*}$ & $0.156^{* *}$ & -0.013 & $0.167^{* *}$ \\
on education & $(0.071)$ & $(0.007)$ & $(0.033)$ & $(0.006)$ & $(0.018)$ & $(0.006)$ & $(0.012)$ & $(0.005)$ \\
Constant & $9.546^{* *}$ & $9.404^{* *}$ & $9.632^{* *}$ & $9.393^{* *}$ & $9.729^{* *}$ & $9.451^{* *}$ & $9.662^{* *}$ & $9.401^{* *}$ \\
& $(0.052)$ & $(0.003)$ & $(0.049)$ & $(0.003)$ & $(0.034)$ & $(0.003)$ & $(0.038)$ & $(0.003)$ \\
Number of observations & 4,076 & 901,895 & 5,225 & 908,298 & 7,366 & 909,119 & 9,430 & 911,396 \\
R-squared & 0.644 & 0.642 & 0.664 & 0.644 & 0.656 & 0.648 & 0.595 & 0.643 \\
\hline
\end{tabular}

Note: All models include: age, age squared, marital status, number of children, country of birth, county or residence, student status, number of employees at the workplace, and occupation on a three-digit level. Robust standard errors in parentheses. ${ }^{* *} \mathrm{p}<0.01,{ }^{*} \mathrm{p}<0.05$ 
Table A4. Return to education by year and temp agency sector/non-temp agency. Women

\begin{tabular}{|c|c|c|c|c|c|c|c|c|}
\hline VARIABLES & $\begin{array}{c}2002 \\
\text { Temp } \\
\text { agency }\end{array}$ & $\begin{array}{l}2001 \\
\text { Other }\end{array}$ & $\begin{array}{c}2002 \\
\text { Temp } \\
\text { agency }\end{array}$ & $\begin{array}{l}2002 \\
\text { Other }\end{array}$ & $\begin{array}{c}2003 \\
\text { Temp } \\
\text { agency }\end{array}$ & $\begin{array}{l}2003 \\
\text { Other }\end{array}$ & $\begin{array}{c}2004 \\
\text { Temp } \\
\text { agency }\end{array}$ & $\begin{array}{l}2004 \\
\text { Other }\end{array}$ \\
\hline $\begin{array}{l}\text { Primary school less than } 9 \\
\text { years }\end{array}$ & \multicolumn{8}{|c|}{ REFERENCE } \\
\hline $\begin{array}{l}\text { Primary school } \\
9(10) \text { years }\end{array}$ & $\begin{array}{c}0.038 \\
(0.023)\end{array}$ & $\begin{array}{l}0.037 * * \\
(0.001)\end{array}$ & $\begin{array}{c}0.034 \\
(0.021)\end{array}$ & $\begin{array}{l}0.036^{* *} \\
(0.001)\end{array}$ & $\begin{array}{c}0.021 \\
(0.020)\end{array}$ & $\begin{array}{l}0.038 * * \\
(0.001)\end{array}$ & $\begin{array}{l}0.046^{*} \\
(0.019)\end{array}$ & $\begin{array}{l}0.039 * * \\
(0.001)\end{array}$ \\
\hline $\begin{array}{l}\text { Upper secondary } 2 \\
\text { years or less }\end{array}$ & $\begin{array}{c}0.036 \\
(0.022)\end{array}$ & $\begin{array}{c}0.054 * * \\
(0.001)\end{array}$ & $\begin{array}{c}0.031 \\
(0.020)\end{array}$ & $\begin{array}{c}0.052^{* *} \\
(0.001)\end{array}$ & $\begin{array}{c}0.018 \\
(0.019)\end{array}$ & $\begin{array}{l}0.051^{* *} \\
(0.001)\end{array}$ & $\begin{array}{l}0.042^{*} \\
(0.019)\end{array}$ & $\begin{array}{l}0.053 * * \\
(0.001)\end{array}$ \\
\hline $\begin{array}{l}\text { Upper secondary } \\
\text { more than } 2 \text { year }\end{array}$ & $\begin{array}{c}0.077 * * \\
(0.022)\end{array}$ & $\begin{array}{c}0.092 * * \\
(0.001)\end{array}$ & $\begin{array}{c}0.065^{* *} \\
(0.020)\end{array}$ & $\begin{array}{c}0.094 * * \\
(0.001)\end{array}$ & $\begin{array}{l}0.047^{*} \\
(0.019)\end{array}$ & $\begin{array}{l}0.096^{* *} \\
(0.001)\end{array}$ & $\begin{array}{c}0.053^{* *} \\
(0.018)\end{array}$ & $\begin{array}{l}0.104^{* *} \\
(0.001)\end{array}$ \\
\hline $\begin{array}{l}\text { Higher education } \\
\text { less than } 3 \text { years }\end{array}$ & $\begin{array}{c}0.101 * * \\
(0.025)\end{array}$ & $\begin{array}{c}0.137 * * \\
(0.001)\end{array}$ & $\begin{array}{l}0.080 * * \\
(0.021)\end{array}$ & $\begin{array}{c}0.137 * * \\
(0.001)\end{array}$ & $\begin{array}{l}0.047^{*} \\
(0.020)\end{array}$ & $\begin{array}{l}0.134 * * \\
(0.001)\end{array}$ & $\begin{array}{l}0.056^{* *} \\
(0.020)\end{array}$ & $\begin{array}{l}0.137 * * \\
(0.001)\end{array}$ \\
\hline $\begin{array}{l}\text { Higher education } 3 \\
\text { years or more }\end{array}$ & $\begin{array}{c}0.154 * * \\
(0.027)\end{array}$ & $\begin{array}{c}0.225^{* *} \\
(0.001)\end{array}$ & $\begin{array}{l}0.125^{* *} \\
(0.023)\end{array}$ & $\begin{array}{l}0.222 * * \\
(0.001)\end{array}$ & $\begin{array}{l}0.090^{* *} \\
(0.022)\end{array}$ & $\begin{array}{c}0.213 * * \\
(0.001)\end{array}$ & $\begin{array}{l}0.058^{* *} \\
(0.021)\end{array}$ & $\begin{array}{l}0.218^{* *} \\
(0.001)\end{array}$ \\
\hline $\begin{array}{l}\text { Post graduate } \\
\text { education }\end{array}$ & $\begin{array}{c}0.078 \\
(0.078)\end{array}$ & $\begin{array}{c}0.398 * * \\
(0.003)\end{array}$ & $\begin{array}{c}0.035 \\
(0.062)\end{array}$ & $\begin{array}{c}0.397 * * \\
(0.003)\end{array}$ & $\begin{array}{c}-0.207 * * \\
(0.023)\end{array}$ & $\begin{array}{l}0.384 * * \\
(0.002)\end{array}$ & $\begin{array}{l}0.460 * * \\
(0.139)\end{array}$ & $\begin{array}{l}0.386 * * \\
(0.002)\end{array}$ \\
\hline Missing value & $\begin{array}{l}0.082^{*} \\
(0.033)\end{array}$ & $\begin{array}{l}0.142 * * \\
(0.005)\end{array}$ & $\begin{array}{l}0.083^{*} \\
(0.041)\end{array}$ & $\begin{array}{l}0.169 * * \\
(0.006)\end{array}$ & $\begin{array}{c}0.125 \\
(0.073)\end{array}$ & $\begin{array}{l}0.164 * * \\
(0.006)\end{array}$ & $\begin{array}{l}0.104 * * \\
(0.031)\end{array}$ & $\begin{array}{l}0.172 * * \\
(0.006)\end{array}$ \\
\hline Constant & $\begin{array}{l}9.208^{* * *} \\
(0.075)\end{array}$ & $\begin{array}{l}9.345^{* *} \\
(0.003)\end{array}$ & $\begin{array}{l}9.356^{* *} \\
(0.071)\end{array}$ & $\begin{array}{l}9.369^{* *} \\
(0.003)\end{array}$ & $\begin{array}{l}9.374 * * \\
(0.062)\end{array}$ & $\begin{array}{l}9.378^{* *} \\
(0.003)\end{array}$ & $\begin{array}{r}9.533^{* * *} \\
(0.066)\end{array}$ & $\begin{array}{l}9.379 * * \\
(0.003)\end{array}$ \\
\hline $\begin{array}{l}\text { Number of observations } \\
\text { R-squared }\end{array}$ & $\begin{array}{l}2,260 \\
0.611\end{array}$ & $\begin{array}{c}862,171 \\
0.647\end{array}$ & $\begin{array}{l}2,730 \\
0.621\end{array}$ & $\begin{array}{c}878,846 \\
0.654\end{array}$ & $\begin{array}{r}3,157 \\
0.635\end{array}$ & $\begin{array}{r}875,540 \\
0.656\end{array}$ & $\begin{array}{l}3,534 \\
0.666\end{array}$ & $\begin{array}{c}874,679 \\
0.643\end{array}$ \\
\hline
\end{tabular}

Note: All models include age, age squared, marital status, number of children, country of birth, county or residence, student status, number of employees at the workplace and occupation on a three-digit level. Robust standard errors in parentheses. ${ }^{* *} \mathrm{p}<0.01,{ }^{*} \mathrm{p}<0.05$ 
Table A4 continued. Return to education by year and temp agency sector/non-temp agency. Women

\begin{tabular}{|c|c|c|c|c|c|c|c|c|}
\hline VARIABLES & $\begin{array}{c}2005 \\
\text { Temp } \\
\text { agency }\end{array}$ & $\begin{array}{l}2005 \\
\text { Other }\end{array}$ & $\begin{array}{c}2006 \\
\text { Temp } \\
\text { agency }\end{array}$ & $\begin{array}{l}2006 \\
\text { Other }\end{array}$ & $\begin{array}{c}2007 \\
\text { Temp } \\
\text { agency }\end{array}$ & $\begin{array}{l}2007 \\
\text { Other }\end{array}$ & $\begin{array}{c}2008 \\
\text { Temp } \\
\text { agency }\end{array}$ & $\begin{array}{l}2008 \\
\text { Other }\end{array}$ \\
\hline $\begin{array}{l}\text { Primary school less than } 9 \\
\text { years }\end{array}$ & \multicolumn{8}{|c|}{ REFERENCE } \\
\hline $\begin{array}{l}\text { Primary school } \\
9(10) \text { years }\end{array}$ & $\begin{array}{c}0.024 \\
(0.017)\end{array}$ & $\begin{array}{c}0.036^{* *} \\
(0.001)\end{array}$ & $\begin{array}{c}0.005 \\
(0.016)\end{array}$ & $\begin{array}{r}0.035 * * \\
(0.001)\end{array}$ & $\begin{array}{c}0.011 \\
(0.011)\end{array}$ & $\begin{array}{c}0.033 * * \\
(0.001)\end{array}$ & $\begin{array}{c}0.016 \\
(0.009)\end{array}$ & $\begin{array}{c}0.029 * * \\
(0.001)\end{array}$ \\
\hline $\begin{array}{l}\text { Upper secondary } 2 \\
\text { years or less }\end{array}$ & $\begin{array}{c}0.021 \\
(0.016)\end{array}$ & $\begin{array}{l}0.051 * * \\
(0.001)\end{array}$ & $\begin{array}{l}-0.006 \\
(0.015)\end{array}$ & $\begin{array}{c}0.049 * * \\
(0.001)\end{array}$ & $\begin{array}{c}0.005 \\
(0.011)\end{array}$ & $\begin{array}{c}0.047 * * \\
(0.001)\end{array}$ & $\begin{array}{l}0.017 \\
(0.009)\end{array}$ & $\begin{array}{l}0.042 * * \\
(0.001)\end{array}$ \\
\hline $\begin{array}{l}\text { Upper secondary } \\
\text { more than } 2 \text { year }\end{array}$ & $\begin{array}{l}0.041^{*} \\
(0.016)\end{array}$ & $\begin{array}{l}0.106^{* *} \\
(0.001)\end{array}$ & $\begin{array}{c}0.009 \\
(0.015)\end{array}$ & $\begin{array}{l}0.107 * * \\
(0.001)\end{array}$ & $\begin{array}{c}0.019 \\
(0.011)\end{array}$ & $\begin{array}{r}0.103 * * \\
(0.001)\end{array}$ & $\begin{array}{l}0.034 * * \\
(0.009)\end{array}$ & $\begin{array}{c}0.103 * * \\
(0.001)\end{array}$ \\
\hline $\begin{array}{l}\text { Higher education } \\
\text { less than } 3 \text { years }\end{array}$ & $\begin{array}{l}0.037^{*} \\
(0.018)\end{array}$ & $\begin{array}{l}0.137 * * \\
(0.001)\end{array}$ & $\begin{array}{l}-0.002 \\
(0.016)\end{array}$ & $\begin{array}{l}0.135 * * \\
(0.001)\end{array}$ & $\begin{array}{c}0.017 \\
(0.012)\end{array}$ & $\begin{array}{l}0.133^{* *} * \\
(0.001)\end{array}$ & $\begin{array}{l}0.031 * * \\
(0.010)\end{array}$ & $\begin{array}{l}0.125 * * \\
(0.001)\end{array}$ \\
\hline $\begin{array}{l}\text { Higher education } 3 \\
\text { years or more }\end{array}$ & $\begin{array}{c}0.059 * * \\
(0.020)\end{array}$ & $\begin{array}{r}0.213 * * \\
(0.001)\end{array}$ & $\begin{array}{c}0.049 * * \\
(0.017)\end{array}$ & $\begin{array}{c}0.212 * * \\
(0.001)\end{array}$ & $\begin{array}{l}0.064 * * \\
(0.013)\end{array}$ & $\begin{array}{r}0.209^{* *} \\
(0.001)\end{array}$ & $\begin{array}{r}0.066^{* *} \\
(0.011)\end{array}$ & $\begin{array}{l}0.196^{* *} \\
(0.001)\end{array}$ \\
\hline $\begin{array}{l}\text { Post graduate } \\
\text { education }\end{array}$ & $\begin{array}{c}0.078 \\
(0.086)\end{array}$ & $\begin{array}{l}0.375^{* *} \\
(0.002)\end{array}$ & $\begin{array}{l}0.369 * * \\
(0.080)\end{array}$ & $\begin{array}{c}0.373 * * \\
(0.002)\end{array}$ & $\begin{array}{c}0.278 * * \\
(0.049)\end{array}$ & $\begin{array}{c}0.369 * * \\
(0.003)\end{array}$ & $\begin{array}{c}0.213^{* * *} \\
(0.065)\end{array}$ & $\begin{array}{c}0.349 * * \\
(0.003)\end{array}$ \\
\hline Missing value & $\begin{array}{c}0.023 \\
(0.071)\end{array}$ & $\begin{array}{c}0.162 * * \\
(0.007)\end{array}$ & $\begin{array}{c}0.042 \\
(0.033)\end{array}$ & $\begin{array}{c}0.162 * * \\
(0.006)\end{array}$ & $\begin{array}{c}-0.037^{*} \\
(0.018)\end{array}$ & $\begin{array}{c}0.155^{* *} \\
(0.006)\end{array}$ & $\begin{array}{l}-0.013 \\
(0.012)\end{array}$ & $\begin{array}{c}0.169 * * \\
(0.006)\end{array}$ \\
\hline Constant & $\begin{array}{c}9.613 * * \\
(0.074)\end{array}$ & $\begin{array}{c}9.388 * * \\
(0.003)\end{array}$ & $\begin{array}{c}9.632 * * \\
(0.049)\end{array}$ & $\begin{array}{c}9.376^{* * *} \\
(0.003)\end{array}$ & $\begin{array}{c}9.729 * * \\
(0.034)\end{array}$ & $\begin{array}{c}9.437 * * \\
(0.003)\end{array}$ & $\begin{array}{c}9.662 * * \\
(0.038)\end{array}$ & $\begin{array}{c}9.385 * * \\
(0.003)\end{array}$ \\
\hline $\begin{array}{l}\text { Number of observations } \\
\text { R-squared }\end{array}$ & $\begin{array}{l}3,979 \\
0.649\end{array}$ & $\begin{array}{c}874,171 \\
0.643\end{array}$ & $\begin{array}{l}5,225 \\
0.664\end{array}$ & $\begin{array}{c}878,483 \\
0.646\end{array}$ & $\begin{array}{l}7,366 \\
0.656\end{array}$ & $\begin{array}{c}879,655 \\
0.650\end{array}$ & $\begin{array}{l}9,430 \\
0.595\end{array}$ & $\begin{array}{c}882,845 \\
0.645\end{array}$ \\
\hline
\end{tabular}

Note: All models include age, age squared, marital status, number of children, country of birth, county or residence, student status, number of employees at the workplace and occupation on a three-digit level. Robust standard errors in parentheses. ${ }^{*} \mathrm{p}<0.01, * \mathrm{p}<0.05$ 
Table A5. Temp agency wage gap by educational level. Men

\begin{tabular}{|c|c|c|c|c|c|c|}
\hline Men & $\begin{array}{c}\text { Primary } \\
\text { school less } \\
\text { than } 9 \\
\text { years }\end{array}$ & $\begin{array}{c}\text { Primary } \\
\text { school } \\
9(10) \\
\text { years }\end{array}$ & $\begin{array}{c}\text { Upper } \\
\text { secondary } 2 \\
\text { years or less }\end{array}$ & $\begin{array}{c}\text { Upper } \\
\text { secondary } \\
\text { more than } 2 \\
\text { years }\end{array}$ & $\begin{array}{c}\text { Higher } \\
\text { education } \\
\text { less than } 3 \\
\text { years }\end{array}$ & $\begin{array}{c}\text { Higher } \\
\text { education } 3 \\
\text { years or } \\
\text { more }\end{array}$ \\
\hline \multirow[t]{2}{*}{ Temp agency work (in 2001) } & $-0.078 * *$ & $-0.025 *$ & $-0.026 * *$ & $0.021 * *$ & 0.024 & -0.003 \\
\hline & $(0.017)$ & $(0.011)$ & $(0.008)$ & $(0.007)$ & $(0.017)$ & $(0.018)$ \\
\hline \multirow[t]{2}{*}{ Temp agency*2002 } & -0.033 & $-0.040 * *$ & $-0.037 * *$ & $-0.061 * *$ & $-0.055 * *$ & $-0.072 * *$ \\
\hline & $(0.024)$ & $(0.015)$ & $(0.011)$ & $(0.009)$ & $(0.020)$ & $(0.023)$ \\
\hline \multirow[t]{2}{*}{ Temp agency*2003 } & -0.021 & $-0.048 * *$ & $-0.042 * *$ & $-0.076^{* *}$ & $-0.080 * *$ & $-0.086^{* *}$ \\
\hline & $(0.022)$ & $(0.014)$ & $(0.011)$ & $(0.009)$ & $(0.020)$ & $(0.021)$ \\
\hline \multirow[t]{2}{*}{ Temp agency*2004 } & $-0.052 *$ & $-0.079 * *$ & $-0.093 * *$ & $-0.133 * *$ & $-0.137 * *$ & $-0.158 * *$ \\
\hline & $(0.023)$ & $(0.013)$ & $(0.010)$ & $(0.008)$ & $(0.019)$ & $(0.020)$ \\
\hline \multirow[t]{2}{*}{ Temp agency*2005 } & -0.003 & $-0.084 * *$ & $-0.092 * *$ & $-0.138 * *$ & $-0.130 * *$ & $-0.119 * *$ \\
\hline & $(0.023)$ & $(0.013)$ & $(0.010)$ & $(0.008)$ & $(0.019)$ & $(0.021)$ \\
\hline \multirow[t]{2}{*}{ Temp agency*2006 } & -0.032 & $-0.117 * *$ & $-0.133 * *$ & $-0.165 * *$ & $-0.166^{* *}$ & $-0.164 * *$ \\
\hline & $(0.022)$ & $(0.013)$ & $(0.009)$ & $(0.008)$ & $(0.018)$ & $(0.020)$ \\
\hline \multirow[t]{2}{*}{ Temp agency*2007 } & $-0.063 * *$ & $-0.119 * *$ & $-0.147 * *$ & $-0.165 * *$ & $-0.188 * *$ & $-0.183 * *$ \\
\hline & $(0.020)$ & $(0.012)$ & $(0.009)$ & $(0.007)$ & $(0.018)$ & $(0.020)$ \\
\hline \multirow[t]{2}{*}{ Temp agency*2008 } & $-0.068 * *$ & $-0.135^{* *}$ & $-0.168 * *$ & $-0.189 * *$ & $-0.215^{* *}$ & $-0.233 * *$ \\
\hline & $(0.020)$ & $(0.012)$ & $(0.009)$ & $(0.007)$ & $(0.017)$ & $(0.019)$ \\
\hline \multirow[t]{2}{*}{ Constant } & $9.549 * *$ & $9.479 * *$ & $9.548 * *$ & $9.453 * *$ & $9.424 * *$ & $9.147 * *$ \\
\hline & $(0.008)$ & $(0.003)$ & $(0.002)$ & $(0.002)$ & $(0.003)$ & $(0.004)$ \\
\hline Number of observations & 322,779 & 669,008 & $1,923,634$ & $1,538,210$ & $1,150,939$ & $1,504,403$ \\
\hline R-squared & 0.444 & 0.525 & 0.506 & 0.602 & 0.597 & 0.627 \\
\hline
\end{tabular}

Note: All models include year dummies, age, age squared, education, marital status, number of children, country of birth, county or residence, student status, number of employees at the workplace and occupation on a three-digit level. Robust standard errors in parentheses. ${ }^{* *} \mathrm{p}<0.01,{ }^{*} \mathrm{p}<0.05$ 
Table A6. Temp agency wage gap by educational level. Women

\begin{tabular}{|c|c|c|c|c|c|c|}
\hline & $\begin{array}{c}\text { Primary } \\
\text { school less } \\
\text { than } 9 \\
\text { years } \\
\end{array}$ & $\begin{array}{c}\text { Primary } \\
\text { school } \\
9(10) \\
\text { years } \\
\end{array}$ & $\begin{array}{c}\text { Upper } \\
\text { secondary } 2 \\
\text { years or less }\end{array}$ & $\begin{array}{c}\text { Upper } \\
\text { secondary } \\
\text { more than } 2 \\
\text { years } \\
\end{array}$ & $\begin{array}{c}\text { Higher } \\
\text { education } \\
\text { less than } 3 \\
\text { years }\end{array}$ & $\begin{array}{c}\text { Higher } \\
\text { education } 3 \\
\text { years or } \\
\text { more }\end{array}$ \\
\hline \multirow[t]{2}{*}{ Temp agency work (in 2001) } & 0.040 & 0.004 & $0.037 * *$ & $0.031 * *$ & $0.086^{* *}$ & $0.083 * *$ \\
\hline & $(0.027)$ & $(0.010)$ & $(0.006)$ & $(0.005)$ & $(0.010)$ & $(0.010)$ \\
\hline \multirow[t]{2}{*}{ Temp agency*2002 } & -0.049 & $-0.034 * *$ & $-0.043 * *$ & $-0.047 * *$ & $-0.047 * *$ & $-0.038 * *$ \\
\hline & $(0.035)$ & $(0.013)$ & $(0.008)$ & $(0.007)$ & $(0.012)$ & $(0.013)$ \\
\hline \multirow[t]{2}{*}{ Temp agency*2003 } & -0.057 & $-0.043 * *$ & $-0.049 * *$ & $-0.054 * *$ & $-0.074 * *$ & $-0.069 * *$ \\
\hline & $(0.034)$ & $(0.013)$ & $(0.008)$ & $(0.007)$ & $(0.013)$ & $(0.013)$ \\
\hline \multirow[t]{2}{*}{ Temp agency*2004 } & -0.070 & $-0.078 * *$ & $-0.103 * *$ & $-0.112 * *$ & $-0.158 * *$ & $-0.179 * *$ \\
\hline & $(0.039)$ & $(0.013)$ & $(0.008)$ & $(0.007)$ & $(0.013)$ & $(0.013)$ \\
\hline \multirow[t]{2}{*}{ Temp agency*2005 } & -0.020 & $-0.052 * *$ & $-0.075 * *$ & $-0.091 * *$ & $-0.136 * *$ & $-0.148 * *$ \\
\hline & $(0.037)$ & $(0.013)$ & $(0.008)$ & $(0.007)$ & $(0.013)$ & $(0.013)$ \\
\hline \multirow[t]{2}{*}{ Temp agency*2006 } & $-0.085^{*}$ & $-0.090 * *$ & $-0.089 * *$ & $-0.105 * *$ & $-0.166 * *$ & $-0.181 * *$ \\
\hline & $(0.039)$ & $(0.013)$ & $(0.008)$ & $(0.007)$ & $(0.013)$ & $(0.012)$ \\
\hline \multirow[t]{2}{*}{ Temp agency*2007 } & $-0.120 * *$ & $-0.092 * *$ & $-0.130 * *$ & $-0.136 * *$ & $-0.210 * *$ & $-0.239 * *$ \\
\hline & $(0.034)$ & $(0.013)$ & $(0.008)$ & $(0.006)$ & $(0.012)$ & $(0.012)$ \\
\hline \multirow[t]{2}{*}{ Temp agency*2008 } & $-0.099 * *$ & $-0.129 * *$ & $-0.166 * *$ & $-0.168 * *$ & $-0.247 * *$ & $-0.289 * *$ \\
\hline & $(0.030)$ & $(0.013)$ & $(0.008)$ & $(0.006)$ & $(0.011)$ & $(0.011)$ \\
\hline \multirow[t]{2}{*}{ Constant } & $9.541 * *$ & $9.458 * *$ & $9.531 * *$ & $9.426 * *$ & $9.534 * *$ & $9.541 * *$ \\
\hline & $(0.007)$ & $(0.002)$ & $(0.002)$ & $(0.001)$ & $(0.002)$ & $(0.002)$ \\
\hline Number of observations & 277,180 & 607,478 & $2,667,756$ & $1,618,050$ & $1,568,727$ & $2,403,887$ \\
\hline R-squared & 0.411 & 0.495 & 0.395 & 0.532 & 0.585 & 0.587 \\
\hline
\end{tabular}

Note: All models include: year dummies, age, age squared, education, marital status, number of children, country of birth, county or residence, student status, number of employees at the workplace, and occupation on a three-digit level. Women in the public sector working less than 75 percent are excluded. Robust standard errors in parentheses. ${ }^{* *} \mathrm{p}<0.01,{ }^{*} \mathrm{p}<0.05$ 